\title{
Kuvallis-materiaalisten lähteiden todistusvoima Ellen Thesleffin marionettien jäljityksessä
}

Kukka Paavilainen

Visuaaliset lähteet - materiaalisine ulottuvuuksineen - ovat taidehistorioitsijan primäärilähteitä. Usein ne jäsentyvät pikemminkin tutkimuksen kohteiksi kuin lähteiksi. Tässä artikkelissa visuaalinen aineisto on sekä tutkimuksen kohteena että muodostaa keskeisimmän osan tutkimuksen lähteistä. Kuvallis-materiaalisia lähteitä korostavalla tutkimusasenteella päästään lähelle tutkittavan teoksen syntyprosessia.

Arvioidessaan Michael Baxandallin tuolloin tuoretta tutkimusta Painting and Experience in Fifteenth Century Italy (1972) Bysantin taiteen tutkija John Shapley pirsi kuvan kahdesta toisistaan erottuvasta suuntauksesta renessanssimaalausten tutkimuksessa. Giovanni Morelli ja Bernard Berenson
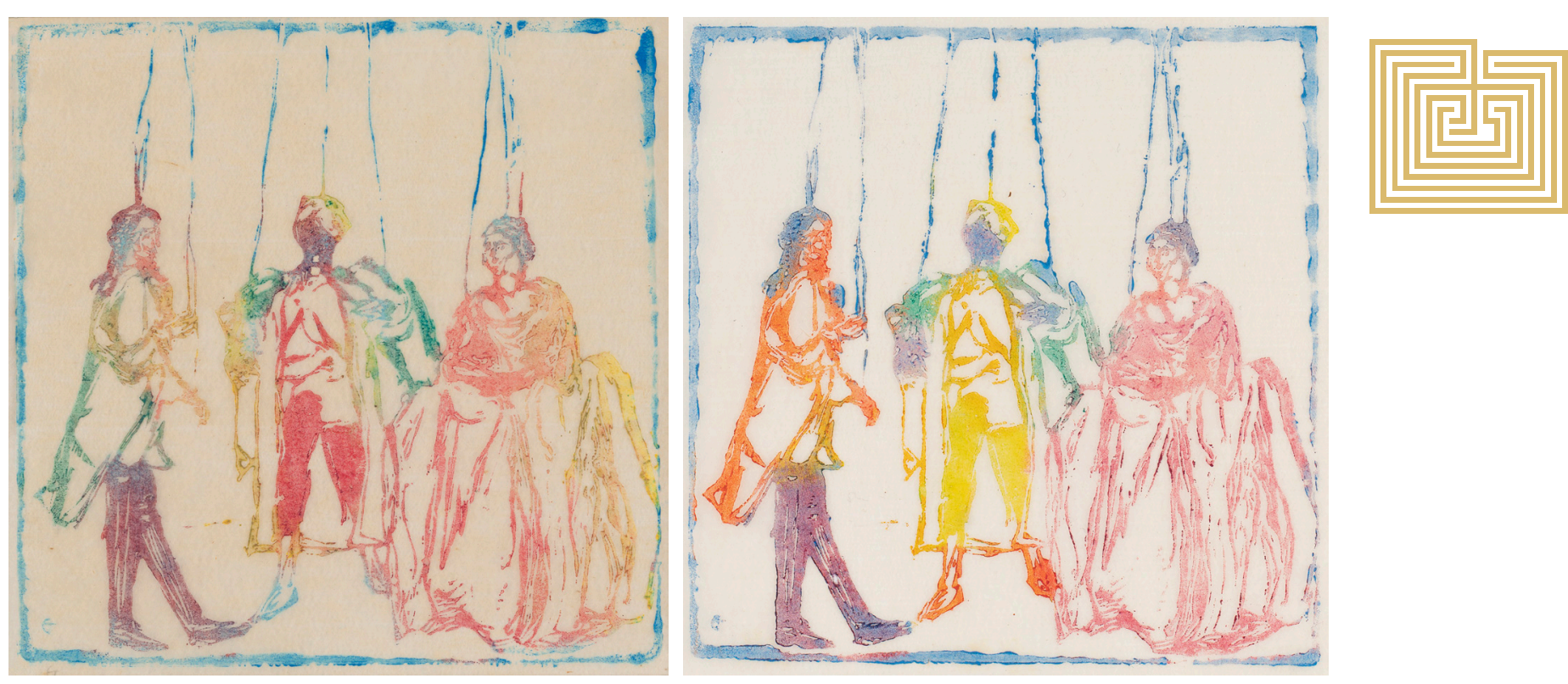

Kuva 1. Ellen Thesleff, Marionetteja, väripuupiiros, painolaatta 1908, 9,5 x 9,5 cm, vedoslehti ajoittamaton. Yksityiskokoelma Tuomo Seppo. Kuva: Kansallisgalleria / Jenni Nurminen.
Kuva 2. Ellen Thesleff, Marionetteja, väripuupiiros, painolaatta $1908,9,5 \times 9,5 \mathrm{~cm}$, vedoslehti ajoittamaton. Yksityiskokoelma. Kuva: HAM / Hanna Kukorelli. 
seuraajineen edustivat attribuointiin keskittyvää linjaa, kun taas Gaetano Milanesi oli aloittanut kirjallisia lähteitä hyödyntävän tutkimussuunnan. Vastakkain joutuivat connoisseurin, taiteentuntijan, originaaliteosten äärellä harjaantunut katse ja kirjeitä, sopimuksia ja ohjekirjoja hyödyntävä taidehistorioitsija. Baxandallin tutkimus kuului jälkimmäisen suuntauksen terävimpään kärkeen - vertautuen peräti historioitsija F. C. Schlosserin julkaisuihin. ${ }^{1}$

Karen Lang palasi taidehistorian tutkimuksen kahtiajakoon käsitellessään Berenson-skandaalia artikkelissaan "Encountering the Object" vuonna 2005. Morelli, jonka oppilas Berenson oli, näki välttämättömäksi, että taidehistorioitsijaksi tähtäävä henkilö hankkisi ensin taiteentuntijan taidot, taiteentuntija kun kykeni tunnistamaan mestariteoksen katseen avulla havaittavien ominaisuuksien perusteella. Käden kokemusta taiteentuntijakaan ei osannut arvostaa. ${ }^{2}$ James Elkins puolestaan korosti artikkelissaan "On Some Limits of Materiality in Art History" (2008), ettei näkemistä tulisi enää erottaa kosketusaistista, tunteista eikä ruumiillisen kokemisen koko kirjosta. ${ }^{3}$ Niinpä katse, kirjallisuus ja käden taidot muodostavatkin ikuisen kolmijalan, jonka varassa taidehistorian tutkimus etenee, milloin mihinkin suuntaan kallistuen.

Yksi tutkimusyhteistyön muoto löytyy konservaattorien ja materiaalitutkijoiden luonnontieteellisistä materiaalianalyyseistä (ns. tekninen taidehistoria). Toinen mahdollisuus käden taitojen yhdistämiseksi tutkimusasenteeseen on taiteellisen tutkimuksen lähestymistavoissa. Edustan itse kahden edellä mainitun yhdistämistä taidehistorioitsijan koulutukseeni Ellen Thesleffin (1869-1954) kohopainotuotannon tarkastelussa. Tässä artikkelissa tarkastelen Marionetteja-puupiirroksen (1907-1908) laatalta vedostettuja monivärisiä vedoksia, niihin liittyviä luonnoksia sekä luonnosten malleina toimineita marionettinukkeja, joiden löytämiseksi tutkimus tehtiin. $^{4}$

Nykyään kirjallisuusorientoitunut lähestymistapa johtaa toisinaan teoreettisen viitekehyksen korostumiseen. Kovin kirjallinen tutkimustulos jää kevyeksi uuden taidehistoriallisen tiedon tuotannon näkökulmasta etenkin, kun sitä tarkastellaan taideteoksiin kiinteästi liittyvän ymmärryksen lisääntymisenä. Visuaaliset aineistot päätyvät kuvittamaan artikkelia, joka ei välttämättä tarvitsisi argumentaationsa tueksi ainoatakaan ku- vaa. ${ }^{5}$ Historioitsija Ludmilla Jordanova tunnistaa ongelman omalla alallaan ja varoittaa artikkelissaan "Approaching Visual Materials" (2011) tilanteesta, jossa visuaaliset lähteet ovat tutkimusta kuvittavassa roolissa ilman, että niillä on keskeinen osa tutkimuksen argumentaatiossa. Taiteentutkimuksellista "heijastusteoriakritiikkiä" mukaillen hän ehdottaa, että passiivisen peilipinnan sijasta visuaalisiin lähteisiin suhtauduttaisiin niiden tekijöiden aktiivisina kommentteina. Tällä tavoin ne otettaisiin vakavasti mukaan perustelemaan historiallista ymmärrystä. ${ }^{6}$ Baxandallille maalaus oli synty-yhteiskuntansa sosiaalisten suhteiden materiaalinen tallenne - huolimatta tutkijan kiinnostuksesta tekstilähteitä kohtaan. ${ }^{7}$ Tässä artikkelissa lähestyn Ellen Thesleffin teoksia ja luonnoksia taiteilijan vakavuudella, niiden todistusarvon huomioon ottaen.

Baxandallilainen perintö elää edelleen 2000-luvulla taiteen ja kulttuurin tutkimuksessa tunnistetun "materiaalisen käänteen" jälkeen. Baxandallille maalaus oli "kaupallisen elämän fossiili" 8 ja siten samanaikaisesti sekä materiaalinen jäännös, arkeologinen aarre että ympäristönsä ei-materiaalisten suhteiden tallenne. Taidehistorian tutkimuk- 


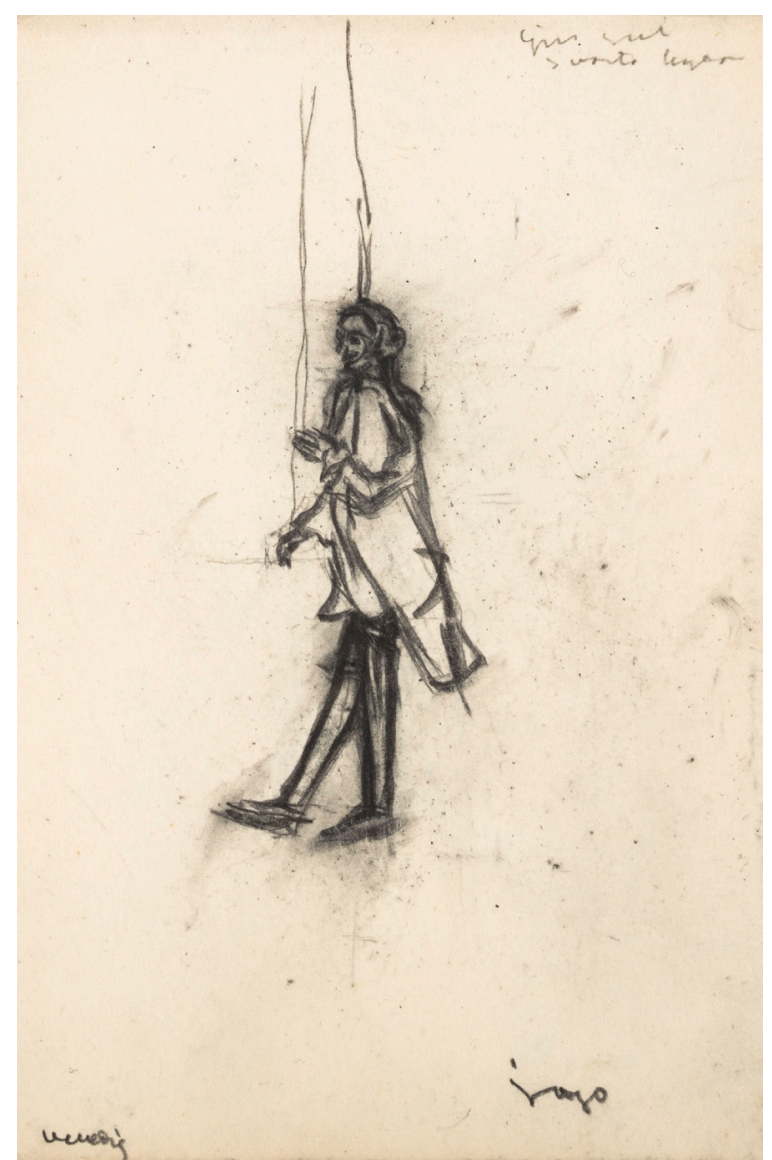

Kuva 3. Ellen Thesleff, Luonnos marionettinukesta "Jago", 1907. Lyijykynä, 11,0 x $15,0 \mathrm{~cm}$. Kansallisgalleria / Ateneumin taidemuseo, Helsinki. Kuva: Kansallisgalleria / Hannu Aaltonen.

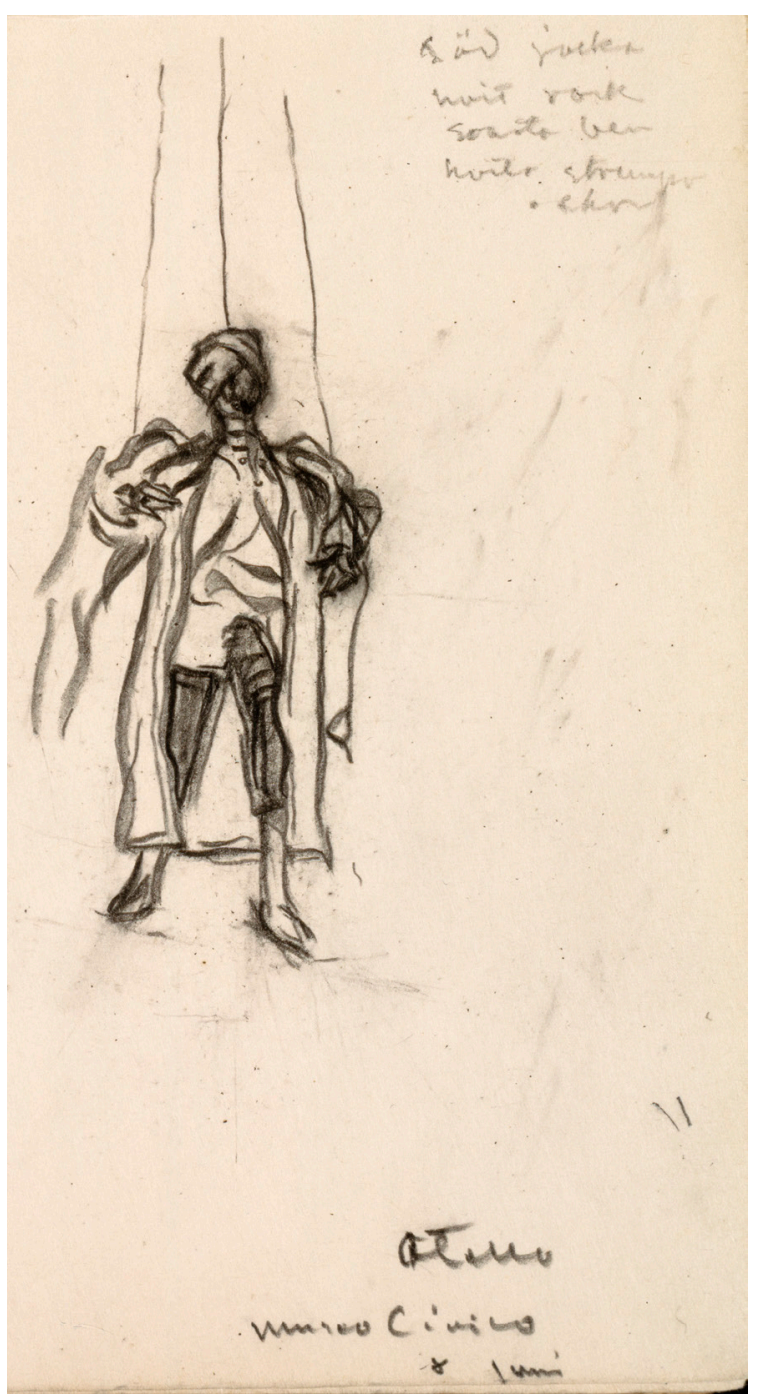

Kuva 4. Ellen Thesleff, Luonnos marionettinukesta "Otello", 1907. Lyijykynä, 11,0 x $15,0 \mathrm{~cm}$. Kansallisgalleria / Ateneumin taidemuseo, Helsinki. Kuva: Kansallisgalleria / Hannu Aaltonen.

sen nykyistä orientoitumista tarkastelemiensa esineiden moniulotteisiin ominaisuuksiin on kritisoitu muun muassa liiallisesta teoreettisuudesta ja konkreettisten taideteosten sivuuttamisesta. Michael Yonan muistuttaa artikkelissaan "The Suppression of Materiality in Anglo-American Art-Historical Writing" (2012), että visuaalisen kulttuurin tutkimuskohteiden kirjosta huolimatta taidehistoria tieteenalana edelleenkin tutkii pääasiassa museossa säilytettäviä esineitä, joiden miellämme kuuluvan "korkeataiteen" piiriin. Hän huomauttaa, että näköaistin perinteinen ensiarvoisuus suhteessa kosketusaistiin istuu syvällä taidehistorian alan opetustavoissa ja siten määrittelee perustavanlaatuisesti niitä haasteita, jotka liittyvät esinetutkimukseen alan sisällä. ${ }^{9}$ Elkins (2008) pyrkii siirtämään fokuksen pois kohteen kuvaluonteesta kohti sen todellisen materiaalisuuden tarkastelua tarkoittaen tällä materian tunnun ja substanssin ymmärrystä. ${ }^{10}$ Artikkelissaan 
"Materiality as Periphery" (2019) Yonan huomioi, kuinka jotkut esinemaailman tutkijat ovat jo ottaneet etäisyyttä ikonografiaan ja siten tutkimuskohteidensa kuvaluonteeseen ja täten siirtäneet huomionsa lähemmäksi esineiden materiaalisuuden tutkimusta. Hän kysyykin, onko mielekästä jakaa yhden ja saman tutkimuskohteen olennaiset piirteet eri tieteenalojen kesken, esimerkiksi taidehistoriaan tai arkeologiaan kuuluviksi. Yonan ehdottaa tilalle visuaalisuuden ja materiaalisuuden yhdistämistä tavalla, joka vaatii kahden tarkastelutavan sovittelevaa rinnakkaineloa saman tutkimuksen sisällä. ${ }^{11}$

Tässä tutkimuksessa lähden liikkeelle primääriaineistojeni visuaalisesta analyysista ja siirryn materiaaliseen tarkasteluun marionettinukkejen löydyttyä. Niin ikään siirryn Thesleffin Marionetteja-puupiirroksen kohdalla teoksen kuvaluonteen käsittelystä kohti materiaalista tarkastelua esitellessäni vedosten sisältämiä väriaineita. Visuaalisuuden ja materiaalisuuden suhde on tarkastelutavassani kiinteä. Jordanovakin kehottaa historioitsijaa lähestymään visuaalista ja materiaalista kulttuuria integroidusti siten, että ne nähdään toisistaan erottamattomina. ${ }^{12}$
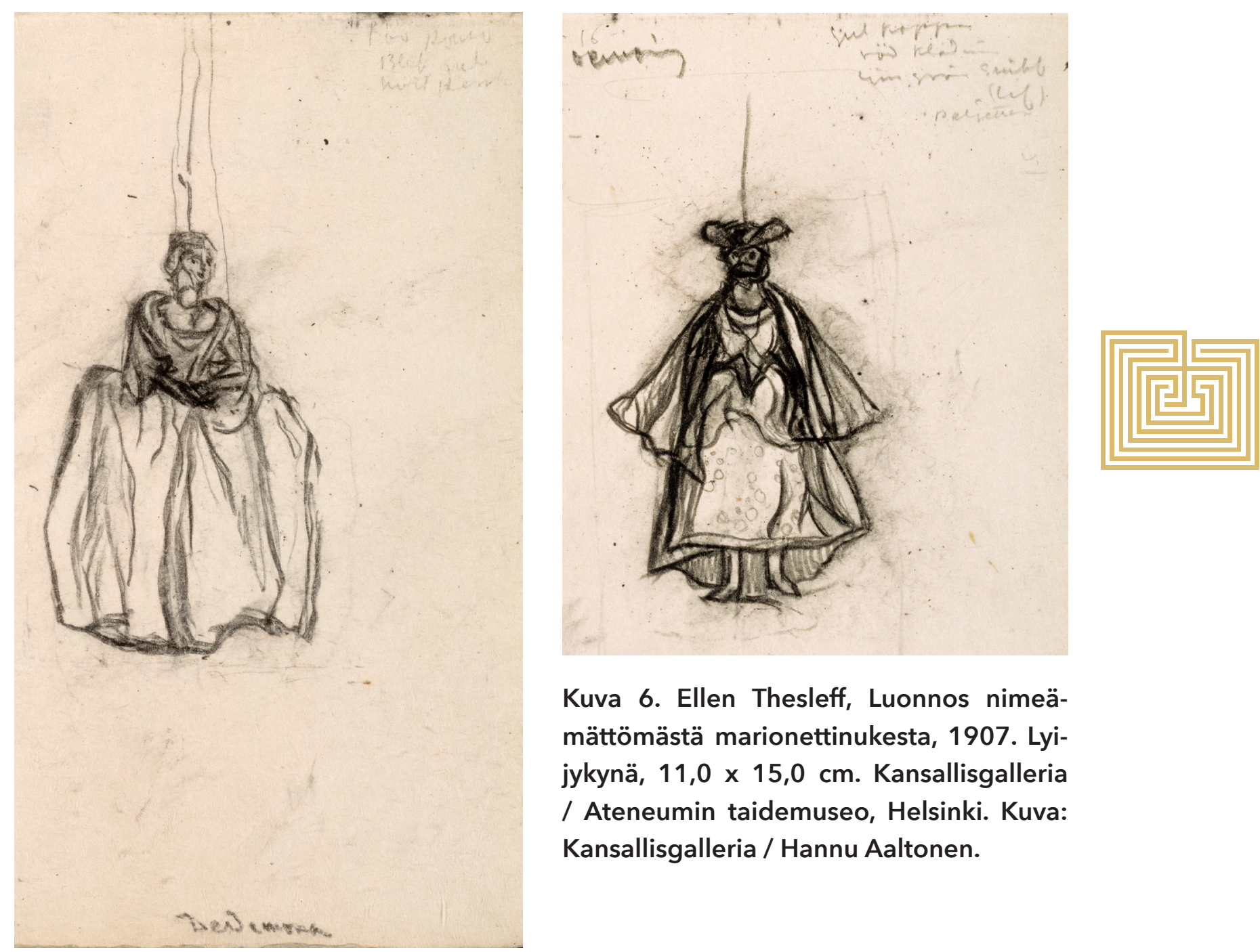

Kuva 5. Ellen Thesleff, Luonnos marionettinukesta "Desdemona", 1907. Lyijykynä, 11,0 x $15,0 \mathrm{~cm}$. Kansallisgalleria / Ateneumin taidemuseo, Helsinki. Kuva: Kansallisgalleria / Hannu Aaltonen. 
Jordanovan mukaan historiantutkimuksessa vallitsee näkemys tekstuaalisten lähteiden suuremmasta luotettavuudesta suhteessa ei-tekstuaalisiin. Hän jatkaa, että teoksen synty-ympäristön ja toteutustekniikan ymmärtämisen tulisi kuitenkin olla ehdoton lähtökohta asian käsittelylle tieteellisessä kontekstissa. ${ }^{13}$ Thesleffin kohopainoteosten kohdalla taiteilijan käyttämät materiaalit ovat jääneet tunnistamatta tähän päivään asti. ${ }^{14}$ Jordanova kehottaa tutkijoita tutustumaan käsittelemiensä teosten tekniikoihin lukemalla niihin liittyvää kirjallisuutta. ${ }^{15}$ Tutkivana taiteilijana haastan taidehistorioitsijakollegani kokeilemaan tutkimiensa teosten toteutustekniikoita. Siihen riittää nuoruuden harrastuneisuus tai muutama kurssi aiheesta - tutkimus ei edellytä aktiivista toimintaa taiteilijana. Haluan korostaa, että käden harjaannuttaminen ja tuntoaistille antautuminen lisäävät materiaalituntemusta ja kehittävät myös katsetta. Siten ne auttavat muotoilemaan uusia, tarkempia tutkimuskysymyksiä ja mahdollistavat myös älyn aiempaa monipuolisemman käytön.

Palataan alun kolmijalkaan. Materiaalitutkija ja konservaattori tutkivat materiaalista kulttuuria, joka vaatii sekä esineen kulttuu- rihistorian tuntemusta ja luonnontieteellisiä menetelmiä että käden pitkälle hiottua suorituskykyä ja materiaalin tunnun tajua. Taiteilija on kiinnostunut teoksen materiaaleista niiden käytön näkökulmasta. Taidehistorioitsijana olen halukas yhdistämään tutkimuksessani materiaalianalyysit, taiteilijan kysymyksenasettelut sekä taidehistorioitsijan lähdekirjallisuuden tuntemuksen ja lähdekritiikin. Tällaisella tutkimusasenteella tutkija orientoituu taiteilijan tavoin kokonaisvaltaisen dialogisesti samanaikaisesti sekä visuaaliseen että materiaaliseen tutkimuskohteeseensa. Ihannetapauksessa tutkijalla olisi siten käytössään niin älynsä, katseensa kuin käden kokemuksensakin. Tutkittavaa kohdetta sitä vastoin tarkasteltaisiin niin visuaaliset kuin materiaaliset aspektit huomioiden ja myös esineen oma historia ja elinkaari hyväksyen.

Tutkimukseni ponnistaa liikkeelle taiteilijan teoslähtöisestä näkökulmasta, jossa oleellista on teoksen tekniikan tuntemus sekä yhden teoksen synnyttämät tutkimuskysymykset. Tutkimukseni ensisijainen tavoite on ollut löytää Thesleffin malleina toimineet marionettinuket. Tämän jälkeen tärkeää on ollut tunnistaa kyseiset nuket,

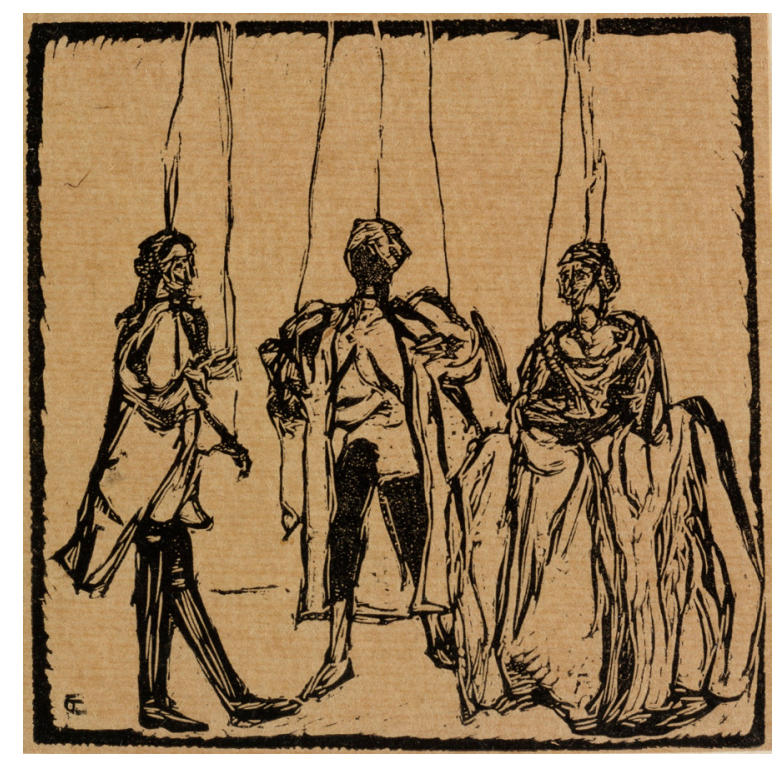

Kuva 7. Ellen Thesleff, Marionetteja, puupiirros (musta), painolaatta 1908, 9,5 x 9,5 $\mathrm{cm}$, vedoslehti ajoittamaton, 10,0 $\times 9,9 \mathrm{~cm}$. Yksityiskokoelma. Kuva: Kansallisgalleria / Janne Tuominen.

sillä Thesleff nimesi kolme neljästä luonnostelemastaan hahmosta William Shakespearen (1564-1616) Othello-näytelmän päähenkilöiden mukaan. Tämä on ollut tutkimuksen kannalta ongelmallista, ellei peräti harhaanjohtavaa. 
Marionetteja-luonnokset 1907 ja julkaisu 1908

Vaikka Ellen Thesleff lukeutuu niihin Suomen taidehistorian vakiintuneisiin nimiin, joiden tuotannosta järjestetään säännöllisesti monografisia näyttelyitä (viimeisimmät 1998, 2008 ja 2019-2020), on taiteilijan varhaisia, vuosien 1907-1910, kohopainoteoksia tutkittu niukasti. ${ }^{16}$ Tässä artikkelissa tarkastelen tämän tuotannon aivan ensimmäistä vuotta, jonka alun ajoitan kesäkuuhun 1907. Tuolloin Thesleff luonnosteli neljä marionettinukkea Museo Civicossa Venetsiassa. Grimani dei Servi -suvulle aikanaan kuuluneet 1700-luvun marionettinuket toimivat myöhemmin Thesleffin tunnetuimman puupiirroksen hahmoina.

Elokuun lopussa 1906 Thesleff suuntasi jo kuudennen kerran Italiaan. ${ }^{17}$ Hän lähti matkaan Gerda-sisarensa kanssa jo ennen Suomen Taiteilijain näyttelyn avautumista Ateneumissa syyskuun puolivälissä. ${ }^{18}$ Näin siitäkin huolimatta, että Thesleffillä oli näyttelyssä esillä kesällä Muroleella maalatut värikkäät ja ekspressiiviset öljyväriteokset Tytöt niityllä, Juhannus (Iltamaisema) ja Lukuhetki (Gerda Thesleff ja Sigrid Schauman) sekä vuotta aiemmin kesäkuussa maalattu
Venetsia. ${ }^{19}$ Jälkeenpäin katsottuna Thesleffiltä jäi siten näkemättä oma koloristinen läpimurtonsa kotimaassa.

Maaliskuussa 1907 Thesleff tutustui Firenzen kansainvälisen kulttuuriväen yhteisössä englantilaiseen teatterin uudistajaan ja graafikkoon Gordon Craigiin (1872-1966), joka suunnitteli uuden The Mask -nimisen teatterilehden julkaisemista. ${ }^{20}$ Lehden ensinumero ilmestyikin maaliskuussa 1908, ja sitä kuvittivat Thesleffin kohopainoteokset. Craig oli saapunut Firenzeen syksyllä 1906 italialaisen näyttelijä Eleonore Dusen kutsumana ohjatakseen Teatteri Pergolassa Henrik Ibsenin Rosmersholm-näytelmän. ${ }^{21}$ Yksi ainoa näytös joulukuussa 1906 oli aiemmin näyttelijänä toimineen Craigin ensimmäinen kahdesta kotimaan ulkopuolella toteutuneesta ja kuuluisaksi tulleesta ohjauksesta harvojen toteutuneiden ohjausten joukossa. ${ }^{22}$

Ennen tutustumistaan Thesleffiin Craig tapasi Firenzessä nuoren brittikirjailija Dorothy Nevile Leesin (1880-1966). Helmikuussa 1907 Lees alkoi kirjoittaa ylös Craigin sanelemia artikkeleita, jotka myöhemmin julkaistiin The Mask -lehden ensimmäisessä vuosikerrassa. Näissä pikakirjoitusistunnoissa Craigin kotona idea The Mask -lehdestä al- koi saada muotonsa. ${ }^{23}$ Tuolloin syntyi yhteistyönä muun muassa Craigin artikkeli "The Actor and the Über-marionette", joka ilmestyi The Maskin toisessa numerossa huhtikuussa 1908. Myös "Madame Eleonore Duselle" osoitettu "avoin kirje" kirjoitettiin tuolloin ja se ilmestyi lehden ensinumerossa. Samoin Craigin näyttelijä-äidille suunnattu kirje "A Letter to Ellen Terry from Her Son" syntyi näiden pikakirjoitusistuntojen aikana ja ilmestyi lehden kuudennessa numerossa elokuussa 1908. Julkaistun kirjeen lopussa on päiväys "Florence, March 18, 1907". ${ }^{24}$

Saman maaliskuun aikana Thesleff siis tapasi Craigin ja tuli näin saapuneeksi Firenzeen keskelle tulevaisuuden teatterilehden ensiaskelia. Craig houkutteli Thesleffin puupiirroksen ja puukaiverruksen pariin. ${ }^{25}$ Thesleff ryhtyi tekemään lehteen Craigin tarvitsemia kuvituksia. Craig toimi lehden taiteellisena johtajana ja "kasvoina", mutta sen käytännön päätoimittajana puursi Dorothy Nevile Lees. Tämä sekä korjasi englanninkielisen lehden artikkelien oikeinkirjoituksen että sujuvasti italiaa puhuvana vastasi toimitustyön vaatimista paikallisista suhteista. ${ }^{26}$ Lees mainitsee muistelmissaan, että Craig pyysi mukaan muitakin kaivertavia taiteili- 
joita. Ellen Thesleff on kuitenkin ainoa, joka tässä yhteydessä mainitaan nimeltä. Thesleff liittyi mukaan pieneen puukaivertajien ryhmään, joka kutsui itseään nimellä "Engravers of San Leonardo". ${ }^{27}$ Ryhmän ex libris -palveluita mainostettiin The Mask -lehden sivuilla aivan alusta lähtien, jo ensimmäisen numeron kansilehden sisäsivulla.

Kolme Thesleffin naamioaiheista pienikokoista puukaiverrusta julkaistiin "A Note on Masks" -artikkelin kuvituksena jo lehden avausnumerossa maaliskuussa $1908 .{ }^{28} \mathrm{Ar}$ tikkelin kirjoitti Gordon Craig peitenimellä John Balance. ${ }^{29}$ Craigin keskeinen artikkeli "The Artists of the Theatre of the Future" aloitti The Mask -lehden ensinumeron ja jatkui lehden kolmannessa, touko-kesäkuun numerossa 1908. Tuon jatko-osan päätteeksi Ellen Thesleffin Marionetteja julkaistiin ensimmäistä kertaa, mustana ja portfoliomaisesti omalla muutoin tyhjällä sivullaan. Teoksen alla näkyi kuvateksti "Marionettes in Venice: lago - Othello - Desdemona" sekä "E. Thesleff". ${ }^{30}$

Marionetteja-vedoksia tunnetaan kuusi päiväämätöntä kappaletta, viisi moniväristä ja yksi musta. ${ }^{31}$ Marionetteja-laatan tekniikan määrittely puupiirrokseksi jää vaille viimeis- tä varmuutta, sillä kaikki Thesleffin varhaiset laatat ovat kadonneet. ${ }^{32}$ Painolaatan puun syiden suunnan mukaan tekniikka määritellään joko puupiirrokseksi (tehty puun halkaisupintaan) tai puukaiverrukseksi (tehty puun katkaisupintaan). ${ }^{33} \quad$ Marionetteja-vedoksia pidetään kuitenkin kaiverrusjäljen perusteella puupiirroksina. ${ }^{34}$ Marionetteja-laattaa pidetään yhtenä Thesleffin varhaisimmista, mutta sen ajoitukselle jo vuodelle 1907 en ole löytänyt perusteita. ${ }^{35}$ Omat tutkimukseni perustan laattojen varhaisimmille esiintymille The Mask -lehden ja muiden julkaisujen sivuilla vuosina 1908-1910. ${ }^{36}$ Siten Marionetteja-laatta on varmuudella ollut valmis toukokuussa 1908. Kaikesta huolimatta Marionetteja-laatta on Thesleffin varhaisimpia ja laatalta vedostetut värivedokset taiteilijan hienoimmiksi mainittuja kohopainoteoksia.

\section{"Venetsia, Museo Civico, kesäkuu"}

Leonard Bäcksbacka mainitsee Ellen Thesleff -monografiassaan (1955) muutamalla virkkeellä Thesleffin luonnostelleen marionettinukkeja Museo Civicossa Venetsiassa kesäkuussa 1907.

Det var först i slutet av 1907 hon på allvar skulle skära ut sina träsnitt. Dessförinnan stude- rade hon i muséerna gamla träsnittplattor och reste i juni till Venedig, där hon i Museo Civico gjorde studier icke blott av träsnitt utan även av marionettdockor. Hon tecknade marionett ${ }^{-}$ figurerna Othello, Desdemona och Jago och annoterade färgerna. Dessa teckningar sammanställde hon till sitt träsnitt "Marionetter" [...].

[Vasta vuoden I9O7 lopulla hän ryhtyi kaivertamaan puupiirroksiaan. Sitä ennen hän tutustui museoissa vanhoihin puupiirroslaattoihin ja matkusti kesäkuussa Venetsiaan, jossa luonnosteli Museo Civicossa ei vain puupiirroksia vaan myöskin marionettinukkeja. Hän piirsi marionettihahmot Othellon, Desdemonan ja Jagon ja merkitsi muistiin värejä. Nämä piirrokset hän yhdisti puupiirrokseensa "Marionetteja" [...].]. $]^{37}$

Taiteilijan luonnoskirja löytyy Kansallisgallerian Ateneumin taidemuseon kokoelmasta. Se sisältää neljä lyijykynäpiirrosta ${ }^{38}$, joista kolme Thesleff on nimennyt William Shakespearen Othello-näytelmän hahmojen mukaan. Aivan kuten Bäcksbacka kertoo, luonnoskirjan sivuilla on tekijän omakätisiä ruotsinkielisiä huomioita marionettinukkejen asujen väreistä ja yksityiskohdista. Niiden lisäksi sivuilla lukee "museo civico", "juni" ja "venedig", mutta vuosilukua ei näiltä lehdiltä löydy.

Näiden kuvien ja sanojen johdattamana lähdin Venetsiaan keväällä 2017 selvittämään, olisiko Thesleffin ikuistamia mario- 


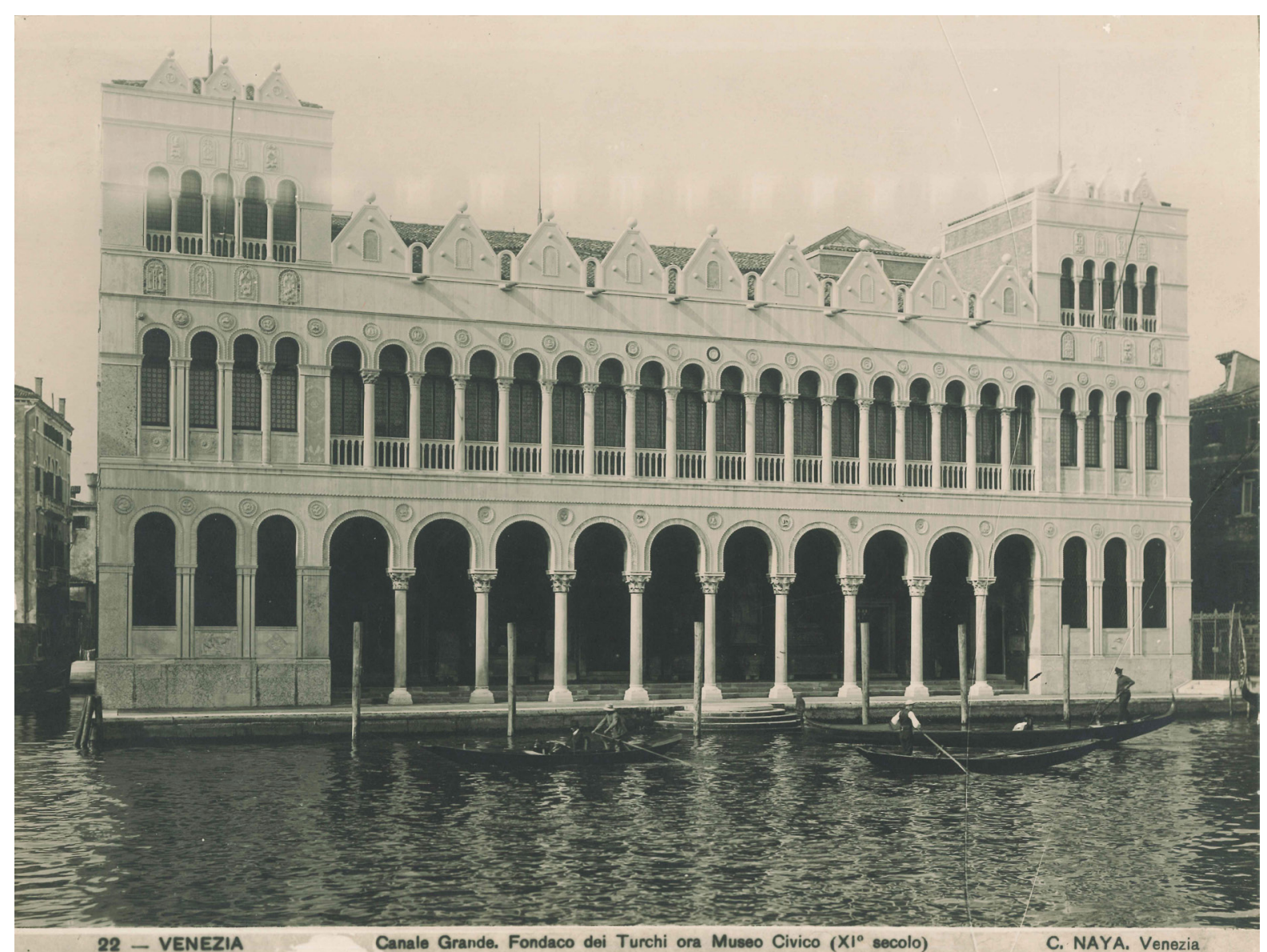

Kuva 8. Carlo Nayan studio, Fondaco dei Turchin julkisivu Canal Grandelta nähtynä. Valokuva, otettu aikavälillä 1887-1918, jolloin Museo Civicon kokoelmat oli sijoitettu Turkin kauppapalatsiin. Museo Correr, Venetsia. nettinukkeja vielä mahdollista löytää. Aloitin puupiirroslaatoista, joihin Bäcksbacka kertoi Thesleffin tutustuneen Venetsian kaupunginmuseossa. Firenzen museoissa ei ole säilynyt ainoatakaan keskiaikaista puupiirroslaattaa, vaan niitä nähdäkseen on matkustettava nimenomaan Venetsian Museo Correriin. ${ }^{39}$ Osa Museo Correrin keskiaikaisista italialaisista puupiirroslaatoista on peräisin jo Teodoro Correrin testamenttilahjoituksesta kaupungille vuonna 1830. Näin ne kuuluivat Museo Civicon kokoelmaan jo Thesleffin vieraillessa museossa kesäkuussa 1907.40 Oman vierailuni aikana sain käyttööni sata vuotta vanhat valokuvat Museo Civicon Fondaco dei Turchin museosalin ripustuksesta. Niiden tarkka ajoitus ei kuitenkaan ollut tiedossa.

Museo Civico, Venetsian kaupunginmuseo, perustettiin aatelismies Teodoro Correrin kuollessa 1830 hänen testamenttinsa ja taidekokoelmansa turvin. Museo avattiin yleisölle vuonna 1836 Correrin kotipalatsissa, mutta vuonna 1887 kokoelma siirrettiin Turkin kauppapalatsiin (Kuva 8). Siellä kokoelma oli esillä aina vuoteen 1922 asti, jolloin se muutti nykyisiin tiloihinsa Piazza San Marcon laidalle. Museo tunnetaan tänä päivänä nimellä 


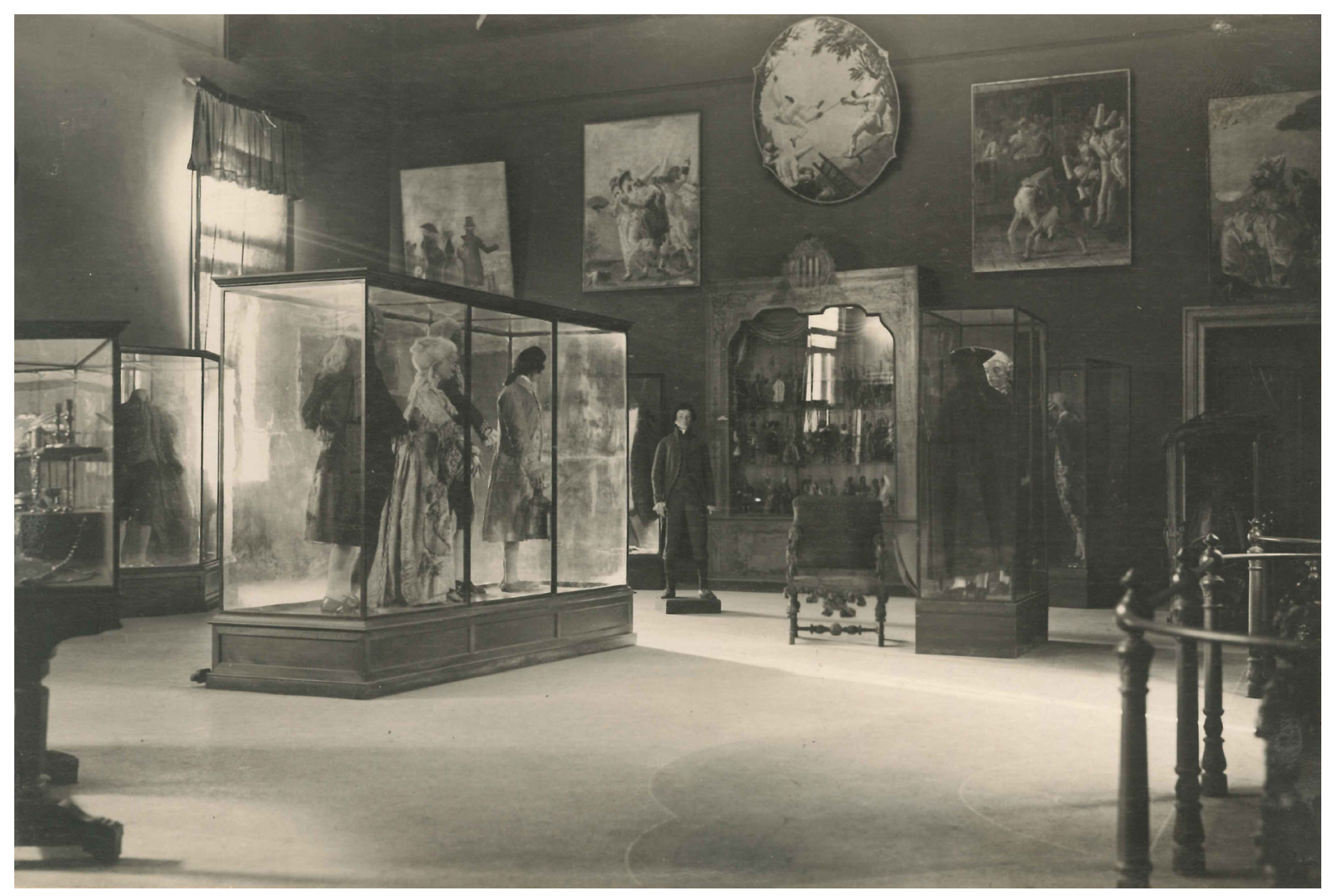

Kuva 9. Carlo Nayan studio, Fondaco dei Turchin näyttelysali. Valokuva, otettu aikavälillä 1896-1918. Museo Correr, Venetsia.
Museo Correr, kun taas Fondaco dei Turchi toimii nykyään Museo di Storia Naturale di Venezian kokoelmien kotina. ${ }^{41}$ Thesleffin vieraillessa Museo Civicossa kesäkuussa 1907 museon kokoelmat olivat esillä Fondaco dei Turchin näyttelysalissa (Kuva 9).

Keskellä valokuvaa komeilee suurikokoinen marionettiteatteri 1700-luvulta. Harvinainen marionettinukkekokoelma oli kuulunut Grimani dei Servin suvulle. Vuonna 1896 se lahjoitettiin Museo Civicolle. ${ }^{42}$ Museo Correr omistaa ainoastaan ne marionettinuket, jotka kuuluivat Grimani dei Servin teatteriin. ${ }^{43}$ Tänä päivänä Museo Correrin marionettinuket on sijoitettu Museo e Centro di Studi Teatrali Casa di Carlo Goldoniin. Commedia dell'arte -näytelmäkirjailija Carlo Goldonin synnyinkoti Ca' Centanni avattiin yleisölle Centro Studi Teatralin avustusten turvin vuonna $1952 .{ }^{44}$ Rakennukseen sijoitettiin myös teatterialan kirjasto, joka on ainutlaatuinen maailmassa.

Biblioteca Casa Goldonin kokoelmissa on teatterilehti La Letturan tammikuun numero vuodelta 1910. Ricciotti Brattin artikkelin "Marionette del settecento" aloitussivulla on lähikuva Museo Correrin omistamasta marionettiteatterista ja muilla sivuilla valokuvia 


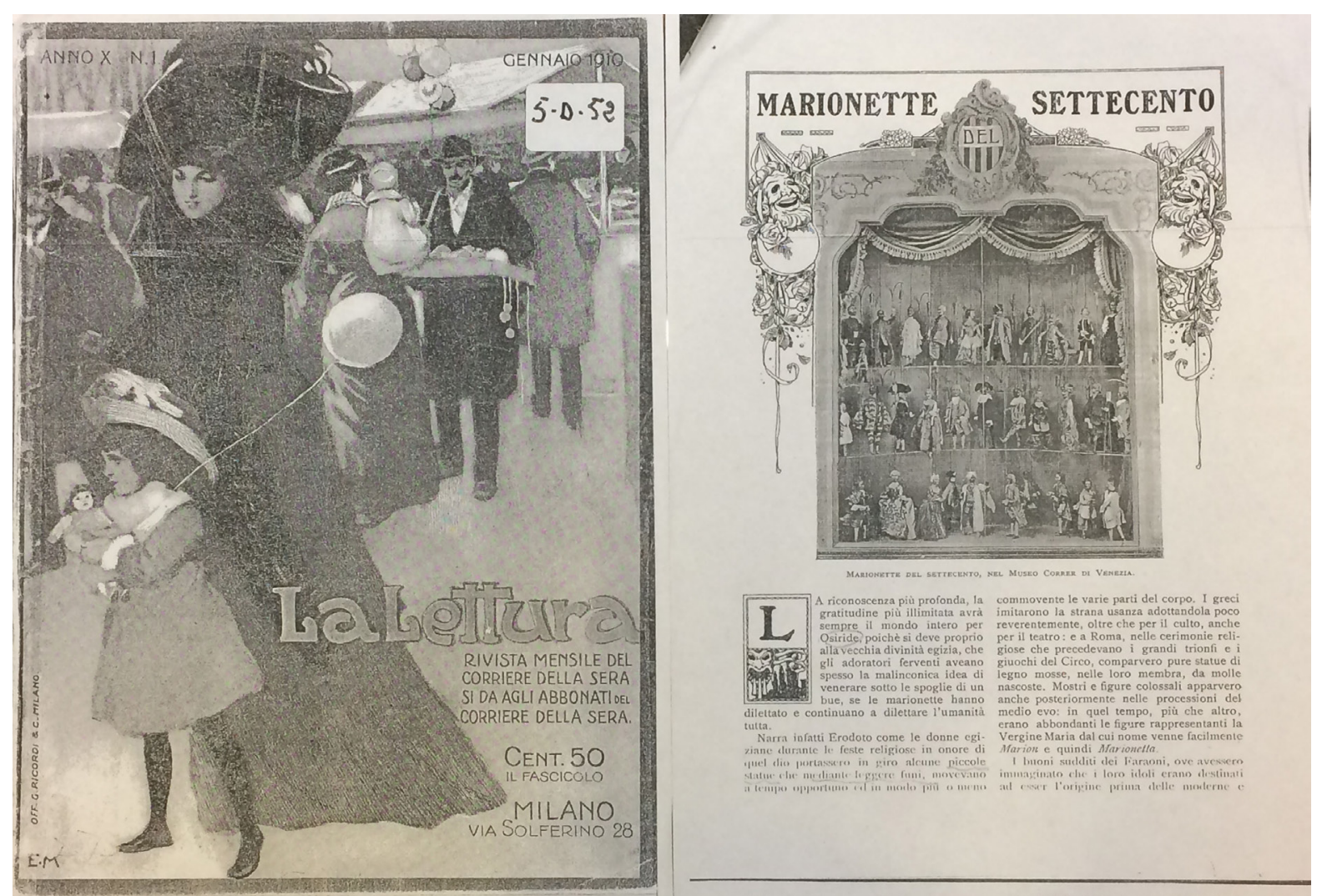

Kuva 10. La Lettura, kansikuva, tammikuu 1910. Rivista mensile del Corriere della Sera, Anno X, n. 1, gennaio 1910. Ricciotti Brattin artikkelin "Marionette del settecento" aloitussivu 59. Museo e Centro di Studi Teatrali Casa di Carlo Goldoni, Venetsia. yksittäisistä nukeista samasta kokoelmasta. Kuvateksti kertoo 1700-luvun marionettinukkejen kuuluvan Museo Correrin kokoelmaan (Kuva 10). ${ }^{45}$ Samainen valokuva marionettiteatterista löytyy edelleenkin museo Correrin kokoelmasta (Kuva 11). Se on aina kuulunut yhteen Fondaco dei Turchin museosalia esittelevän valokuvan kanssa. Lähikuvan alareunasta löytyy runsaasti informaatiota: valokuvan on ottanut Carlo Naya (Venetsia) ja sen aiheena on "Teatteri ja 1700-luvun marionetit Museo Civicossa". ${ }^{46}$

Carlo Naya (1816-1882) oli kansainvälisesti palkittu venetsialainen valokuvaaja. Hän asettui kaupunkiin vuonna 1857 ja avasi studion, joka kuvasi runsaasti taideteoksia ja arkkitehtuurikohteita sekä pittoreskeja kaupunkinäkymiä Venetsiasta. ${ }^{47}$ Hänen kuoltuaan vuonna 1882 studiota jatkoivat hänen leskensä ja tämän uusi puoliso aina vuoteen 1918 asti. ${ }^{48}$ Naya oli siten ehtinyt kuolla jo ennen kuin Museo Civicon kokoelmat siirtyivät Fondaco dei Turchiin vuonna 1887. Näin ollen rakennuksen julkisivunkin on kuvannut Nayan studio aikavälillä 1887-1918 (Kuva 8). Kuvateksti kertoo rakennuksen "nyt" (ital. "ora") olevan Museo Civico. Grimani dei Servi -suvun marionettiteatteri lahjoitet- 


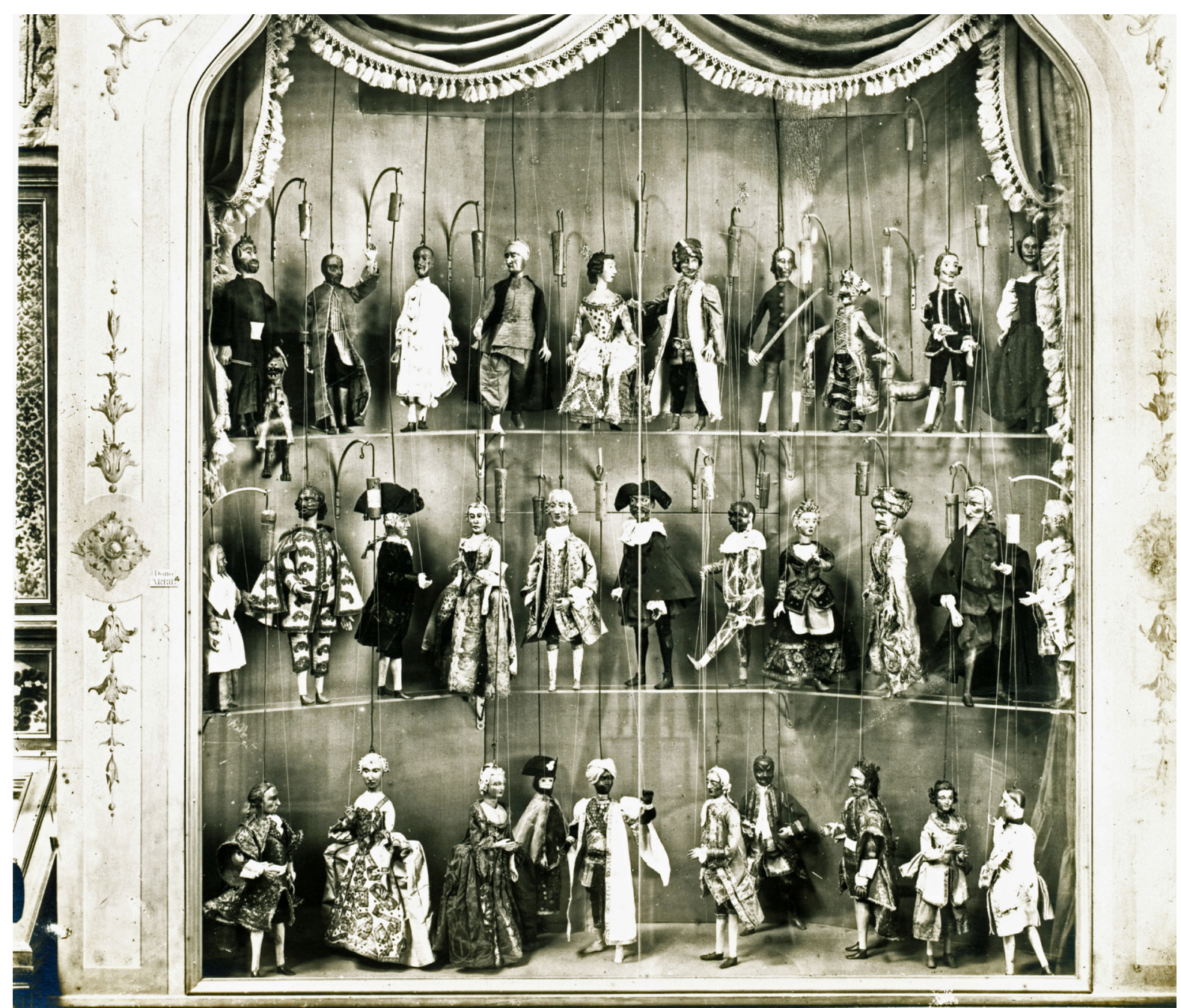

3364 - VENEZIA
C. NAYA - Veneria

Kuva 11. Carlo Nayan studio, Grimani dei Servi -suvun marionettiteatteri Museo Civicossa Venetsiassa. Valokuva, otettu aikavälillä 1896-1910. Museo Correr, Venetsia.

tiin Venetsian kaupunginmuseon kokoelmiin vasta vuonna 1896. Siten Nayan studion on täytynyt kuvata marionettiteatterin lähikuva vuoden 1896 ja tammikuun 1910 välillä. Marionettien ripustus Fondaco dei Turchin näyttelysalissa on mitä ilmeisimmin pysynyt samana Thesleffin vierailusta museossa kesäkuussa 1907 aina tammikuuhun 1910 asti.

Nayan studion ottamassa lähikuvassa näemme neljä hahmoa keskellä alinta hyllyä (Kuva 11). Marionettinukkejen tunnistamista helpottaakseni olen tehnyt kyseisistä neljästä hahmosta detaljikuvan (Kuva 12) ja kääntänyt Kansallisgallerian Marionetteja-värivedoksen peilikuvaksi Photoshop-ohjelman avulla (Kuva 13).

Museo Civicon marionettinuket edustivat kukin tunnistettavaa hahmoa venetsialaisessa 1700-luvun yhteiskunnassa. Nuken sosiaalinen status tuli ilmi tämän vaatetuksessa, jota ei vaihdettu. ${ }^{49}$ Thesleffin valinta nimetä luonnostensa hahmot Othello-näytelmän päähenkilöiden mukaan on johdatellut tutkijoita voimakkaasti pois nukkejen itsensä edustamista rooleista. Tämä johtunee siitä, ettei nukkejen olemassaolosta ole aiemmin ollut tietoa. Vuonna 1998 Salme Sarajas-Korte identifioi hahmot Shakespearen 


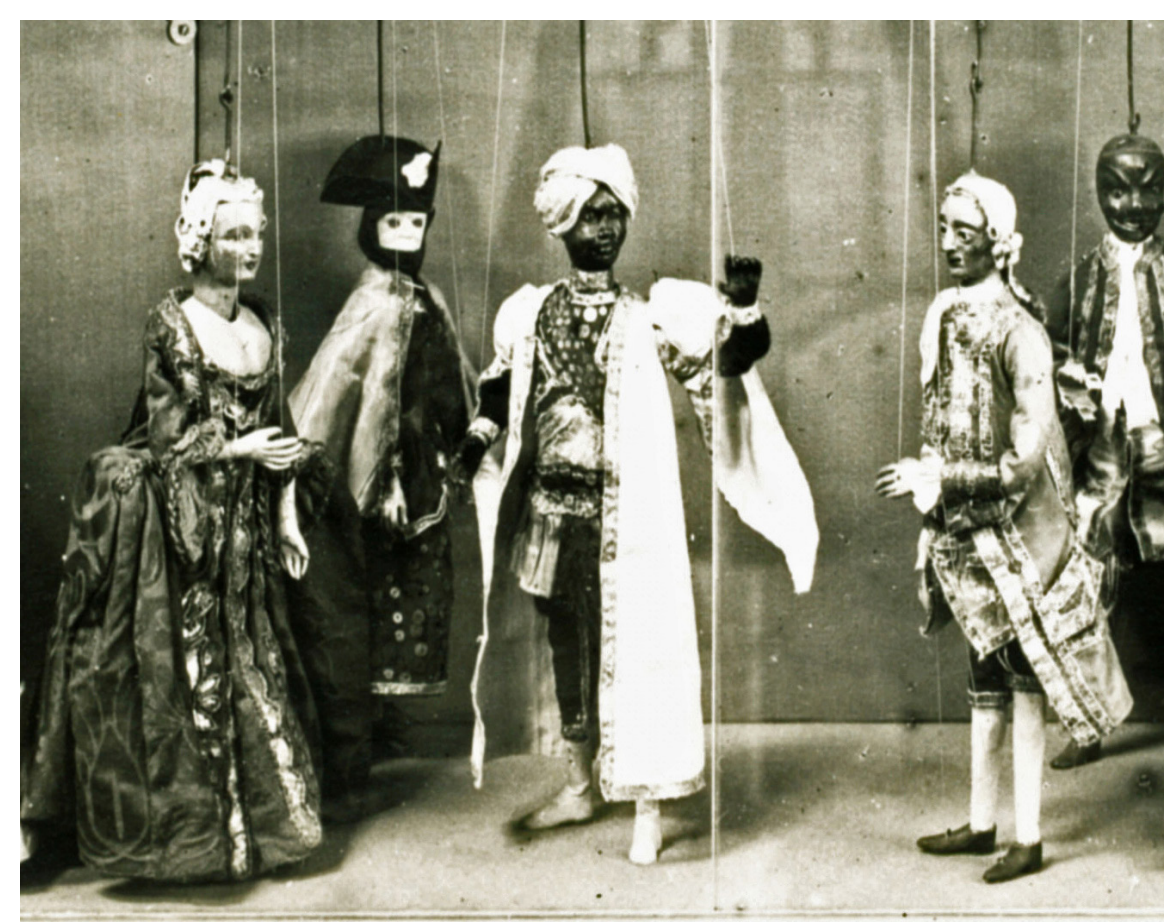

Kuva 12. Yksityiskohta kuvasta 11, marionettiteatteri Museo Civicossa. Museo Correr, Venetsia.

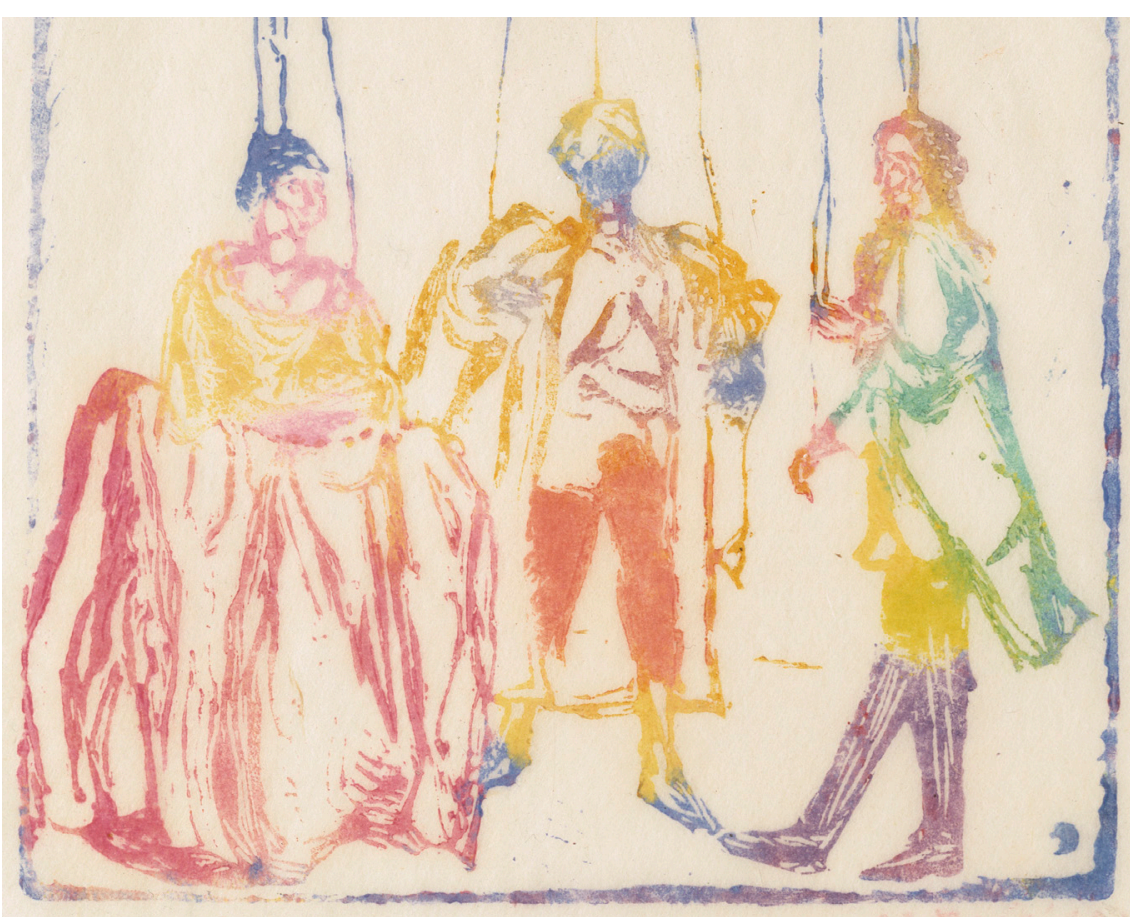

Kuva 13. Ellen Thesleff, Marionetteja, osa kuvasta 18 peilikuvana.

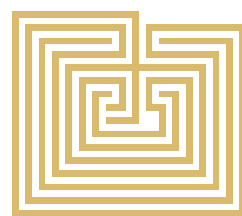

Othello-näytelmän (ensies. 1604) Othelloksi, Desdemonaksi ja Jagoksi ja oletti neljännen hahmon Venetsian Dogeksi. ${ }^{50}$

Hanna-Reetta Schreckin (2017) mukaan teos "kuvaa Gordonin [Craig] työstämää Shakespearen Othelloa", mutta tutkija ei kerro mihin tieto perustuu. ${ }^{51}$ Craig työsti Firenzessä liikkuvan näyttämön pienoismal- liaan jo kesästä 1907 lähtien eli pian tavattuaan Thesleffin. Konstantin Stanislavskin kutsu ohjata Shakespearen Hamlet Moskovan Taiteelliseen Teatteriin saapui Craigille toukokuussa 1908 eli samassa kuussa, jolIoin Thesleffin Marionetteja julkaistiin The Maskissä. Jo tätä ennen Craig oli työstänyt näytelmää pienoismallinsa avulla ja sen vai- kutus näytelmän lavastukseen oli merkittävä. Hamletin toteutus venyi monivuotiseksi ja ensi-ilta nähtiin Moskovassa lopulta vasta tammikuussa $1912 .{ }^{52}$ Thesleff palasi Suomeen jo syyskuussa $1909 .{ }^{53}$

Myös E. J. Vehmas (1970) piti Marionetteja-teoksen aiheena "marionettinäytelmän Othellon" päähenkilöitä ja katsoi Thesleffin 
ratkaisseen vaikean sommittelutehtävän eheästi. ${ }^{54}$ Thesleff oli kuitenkin tässä suhteessa onnekas: nuket oli valmiiksi aseteltu vieretysten. Hänen ei tarvinnut kuin hieman liikkua marionettien edessä etsiessään parasta mahdollista kulmaa kunkin nuken asennon ja asun esittämiseen. Näillä marionettinukeilla ei tiettävästi kuitenkaan ole mitään tekemistä Shakespearen Othello-näytelmän kanssa. Museo Civicon nukeilla ei ole esitetty Shakespearen, Carlo Goldonin tai muidenkaan näytelmäkirjailijoiden näytelmiä enää niiden museokokoelmaan liittämisen jälkeen eli vuodesta 1896 lähtien. ${ }^{55}$

On kuitenkin periaatteessa mahdollista, että Thesleff olisi voinut nähdä aikalaismarionettiteatterin esittävän Shakespearen näytelmiä. Guido Marta esimerkiksi mainitsee II Gazzettino Illustrato -aikakauslehdessä vuonna 1926, että jokin marionettiteatteri olisi esittänyt Macbeth-näytelmän. Esityksen ajankohta ei kuitenkaan ole tiedossa. ${ }^{56}$

1700-luvun venetsialainen yhteiskunta Tarkastellaan seuraavaksi Nayan studion lähikuvaa marionettinukkekokoelmasta (Kuva 11). Valokuvassa näkyy, että Fondaco dei Turchin marionettiripustuksessa oli

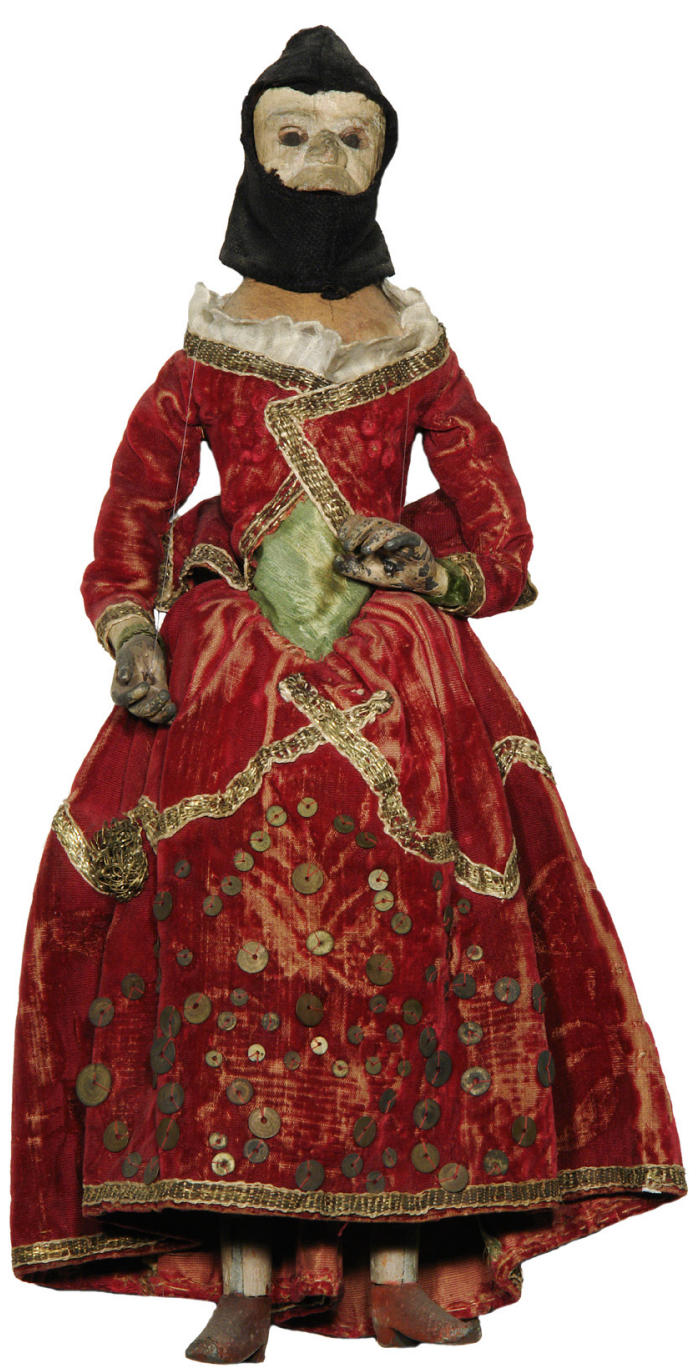

Kuva 14. Dama con maschera e bauta, venetsialainen marionettinukke, 1700-luku. Museo e Centro di Studi Teatrali Casa di Carlo Goldoni, Venetsia. kuvanottohetkellä esillä kolmekymmentäyksi henkilöhahmoa sekä lammas ja leopardi. Marionettiripustuksen keskirivillä näemme commedia dell'arten hahmoja, esimerkiksi viidentenä oikealta on Harlekiini naamio kasvoillaan. Toinen harlekiini näkyy alarivillä. Valkopukuinen Pulcinella-hahmokin kuuluu säilyneisiin nukkeihin, mutta se ei ollut Thesleffin vierailun aikaan esillä. ${ }^{57}$ Sen sijaan hahmo seikkailee Giandomenico Tiepolon (1727-1804) maalauksissa marionettiteatterin yläpuolella Fondaco dei Turchin näyttelysalissa (Kuva 9). Nämä kolme maalausta kuuluvat nykyään Ca' Rezzonico -museon kokoelmaan, joka on osa vuonna 2008 perustettua Fondazione Musei Civici Venezian museoverkostoa. ${ }^{58}$ Keskimmäinen ovaalinmuotoinen Tiepolon maalaus on Pulcinellan keinu (1783). Sen oikealla puolella näemme maalauksen Pulcinella ja akrobaatit (1791-1793) ja vasemmalla puolella Rakastuneen Pulcinellan (1793-1797). ${ }^{59}$

Marionettiripustuksen alariville on koottu venetsialaista aristokratiaa, joka niin ikään oli keskeisessä rakastuneen pääparin roolissa commedia dell'arte -näytelmissä. He esiintyivät ilman naamioita ja kantoivat yllään elegantteja, aikakauden viimeisimmän 
muodin mukaisia asuja. Näytelmän lopussa juhlittiin pääparin häitä. ${ }^{60}$ Usein tärkeä rooli oli myös kamarineidoilla, jotka sekaantuivat rakastuneen parin edesottamuksiin. Kamarineidon tunnistaa syvään uurretusta dekolteesta. ${ }^{61}$ Heitä näkyy valokuvassa kolme. ${ }^{62}$ Miespuolisia palvelijoita näkyy ripustuksen oikeassa ylä- ja alakulmassa. Keskirivin vasemmalta laidalta erottuu puolestaan yhteiskunnan vähäosainen. ${ }^{63}$

Esillepanon ylärivi on kansoitettu Venetsian etnisiä vähemmistöjä ja laajoja kauppasuhteita edustavilla hahmoilla. Vasemmalla rivin tosin aloittaa itse Paholainen, mutta tämän jälkeen seuraavana on itämainen kauppias, sitten kiinalainen, [kadonnut nukke], kamarineito, turkkilainen, pienviljelijä, jälleen turkkilainen ja lopulta mies- ja naispuolinen palvelija. ${ }^{64}$ Valokuvassa näkyvät hahmot ovat siten yhtä lukuun ottamatta säilyneet meidän päiviimme asti. Esillä olleiden kolmenkymmenenyhden henkilöhahmon ja kahden eläimen lisäksi säilyneisiin nukkeihin kuuluu kaikkiaan vielä kymmenen henkilöhahmoa, joiden joukossa on myös mauri. Esillepanon keskushahmoksi on valittu toinen, vauraampi mauri. Molempien nimi Patrizia Bonaton teosluettelossa on Moro. ${ }^{65}$
Mauri seisoo ohjauslankojensa varassa alarivin keskellä ylhäisen naisen ja herrasmiehen välissä. Daamin ja maurin takaa näkyy karnevaaliasuinen hahmo. Tätä nukkea Thesleff ei nimennyt eikä sisällyttänyt Marionetteja-laatalleen.

Thesleffin kirjalliset huomiot neljän luonnoksen lehdellä ovat kuitenkin rikkaimmat juuri kyseisen nuken kohdalla: "gul kappa, röd klädning, ljus grön snibb (lif), paljetter". Daami on pukeutunut keltaiseen viittaan ja punaiseen leninkiin, jonka miehustassa on vaaleanvihreä kulmikas muoto. Lisäksi asussa on paljetteja, joita Thesleff on piirtänyt runsaasti pitkin helmaa (Kuva 6).

Italiaksi hahmon nimi on "Dama con maschera e bauta" (Kuva 14). Hahmolla on aikakaudelle tyypillinen venetsialainen karnevaaliasu, johon kuului valkoinen naamio, kolmikolkkahattu ja kasvot peittävä musta päähine, joka on osa hartiat peittävää viittaa. Tästä kokonaisuudesta käytetään edelleenkin nimitystä "bauta". 66

Kun vertaamme daamia nukkeen nykyasussaan, huomaamme, että tämä on menettänyt komean kolmikolkkahattunsa sekä lyhyen viittansa. Tricorno-päähineen ja viitan katoaminen on huomioitu myös vuonna 1980

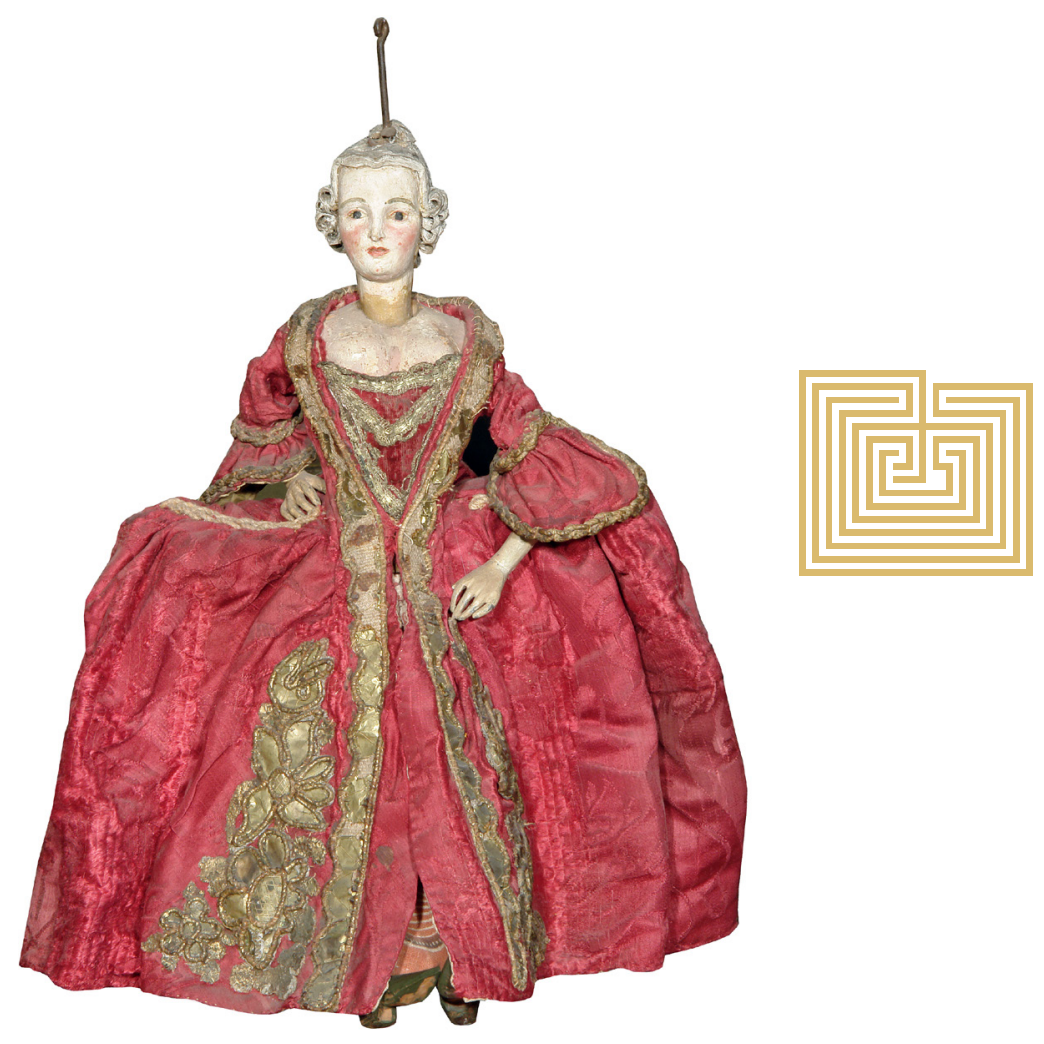

Kuva 15. Dama (Donna Silvia), venetsialainen marionettinukke, 1700-luku. Museo e Centro di Studi Teatrali Casa di Carlo Goldoni, Venetsia. 
toteutetussa konservoinnissa. Daamilla on edelleen metallipaljetein koristeltu punainen samettileninkinsä, johon kuuluu vaaleanvihreä silkkikorsetti. ${ }^{67}$ Myös kolmikolkkahatun alle kuuluva musta pään peittävä huntu on tallella, samoin valkoinen naamio "larva". Nayan studion valokuvassa daami on täydellisessä asussaan hyvä esimerkki venetsialaisten suosimasta karnevaaliasusta (Kuva 11).

Thesleffin Desdemona on Dama (Donna Silvia), venetsialainen nainen (Kuva 15). ${ }^{68}$ Thesleffin muistiinpanoissa lukee "Röd ponso, Blek gul, hvit peruk". "Röd ponso" on punaisen sävy. Teosluettelon mukaan peruukin valmistuksessa on käytetty valkoista gessomaalia.(Kuva 5). ${ }^{69}$ Commedia dell'arten pääosaa esittävän rakastajattaren tunnettuja nimiä olivat Silvia ja Rosaura. ${ }^{70}$ Valokuvassa Donna Silvian vasemmalla puolella näkyy toinen daami, Dama Rosaura nimeltään. ${ }^{71}$ Thesleffin muistiinpano kalpeasta keltaisesta väristä liittynee hahmon asun kultaiseen koristeluun, joka Thesleffin on täytynyt vedoksessaan korvata muulla värillä, sillä Kansallisgallerian Marionetteja-vedoksesta ei löytynyt kultaa. ${ }^{72}$ Niinpä on mahdollista, että taiteilija jo tässä vaiheessa olisi miettinyt teoksen toteutusta värien näkökulmasta.

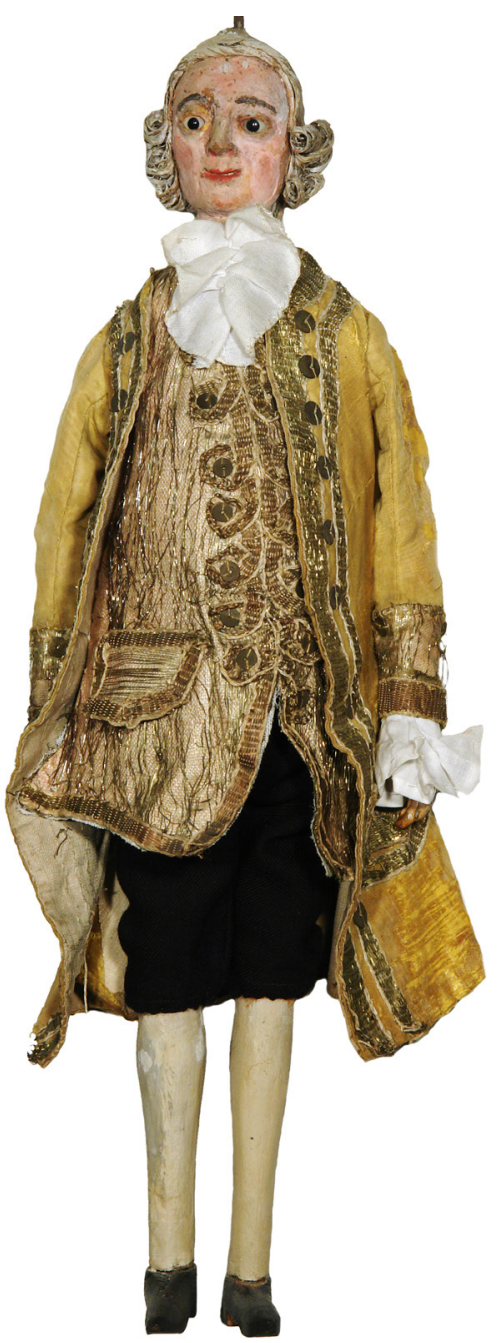

Kuva 16. Gentiluomo (Florindo), venetsialainen marionettinukke, 1700-luku. Museo e Centro di Studi Teatrali Casa di Carlo Goldoni, Venetsia.
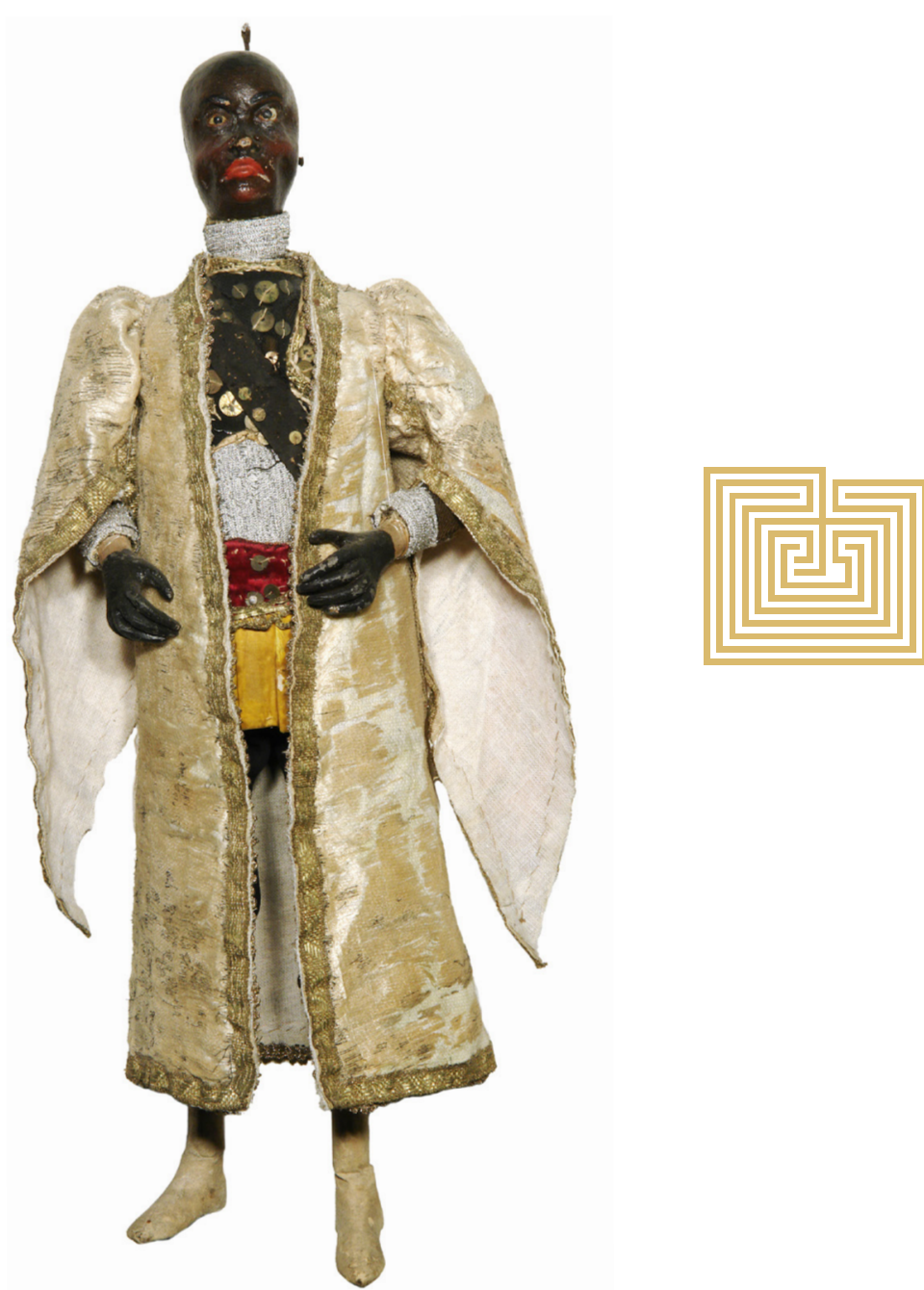

Kuva 17. Moro, venetsialainen marionettinukke, 1700-luku. Museo e Centro di Studi Teatrali Casa di Carlo Goldoni, Venetsia. 
Thesleffin Jago puolestaan on Gentiluomo (Florindo), venetsialainen herrasmies (Kuva 16). ${ }^{73}$ Hänen asustaan Thesleff on kirjannut ylös "ljus gul, svarta byxor" eli värin vaaleankeltainen ja mustat housut (Kuva 3). Marionettinukella on peruukki, jonka niskassa on palmikko. ${ }^{74}$ Se näkyy harmaana Kansallisgallerian vedoksessa (Kuva 18). Commedia dell'arten miespuolisten rakastajien tunnettuja nimiä olivat muun muassa Florindo, Lelio ja Lindoro. ${ }^{75}$ Marionettiteatterin keskiriviltä, viidentenä vasemmalta löytyykin runoilija Lelio, ja kolmantena vasemmalla näemme Lindoron kolmikolkkahatussaan. ${ }^{76}$ Keväällä 2017 muiden marionettien roikkuessa painovoiman mukaisesti raajat suoraan alaspäin Florindon jalat suuntasivat eteenpäin. Ne muistuttivat vahvasti Thesleffin luonnokseensa voimakkaalla viivalla piirtämää eteenpäin sojottavaa alaraajaa.

\section{Puupiirroslaatta}

Laatalle päätyneistä nukeista Donna Silvian ja Florindon asut olivat tyypillisiä rokokoo-asuja. Maurin asussa puolestaan oli runsaammin sekoittuneita vaikutteita. Pitkä päällystakki edusti jo 1500-luvulla käytössä ollutta venetsialaista mallia. ${ }^{77}$ Thesleffin muis- tiinpanojen mukaan maurin asu on ruotsiksi: "Röd jacka, hvit rock, svarta ben, hvita strumpor, skarf" (Kuva 4). Maurilla on punainen takki, valkoinen päällystakki, mustat jalat ja valkoiset sukat sekä päässään huivi, jota tällä ei enää ole. Mauri esiintyy valokuvassa ilman turbaaniaan jo vuoden 1967 julkaisussa. ${ }^{78}$ Nuken päällystakki on norsunluunvalkoista silkkiä ja sääreen ulottuvat housut mustaa silkkiä. Thesleffin punaiseksi mainitsema takki on mustaa villaa ja koristeltu metallipaljetein, mutta se suljetaan vyötäisiltä punaisella vyönauhalla. Thesleffin "sukat" ovat nilkkaan ulottuvat kengät, jotka on valmistettu valkoisesta kilinnahasta. Nuken kämmenet on maalattu mustalla värillä ranteeseen asti. $^{79}$

Marionettihahmo on italiaksi Moro. Tämä on korkeaan asemaan 1700-luvun venetsialaisessa yhteiskunnassa noussut henkilö, jolla on muihin marionettinukkeihin nähden tummempi ihonväri. ${ }^{80}$ Hänen asunsa on - jos mahdollista - vielä Donna Silviaa ja Florindoakin loisteliaampi. Thesleff on nimennyt marionettiripustuksen päähenkilön näytelmän italiankielisen nimen mukaisesti Otelloksi (Kuva 4).

Jos nyt vertaamme mustaa Marionetteja-vedosta Thesleffin luonnokseen kesäkuul- ta 1907 huomaamme, että maurin asento ja askellus ovat siirtyneet luonnokselta laatalle peräti identtisinä (Kuvat 4 ja 7). Vedoksen kuva on peilikuva luonnokseen nähden. Niin Moron eteen kohottama mustan housun verhoama reisi, liehuvat päällystakin avarat hihat kuin turbaanin muotoilukaan eivät ole kokeneet muutoksia siirryttäessä luonnoksesta laatalle.

Siirrytään tarkastelemaan Thesleffin monivärisiä vedoksia ja hänen niihin valitsemiaan vedostusvärejä. Kansallisgallerian Marionetteja-vedoksen ${ }^{81}$ (Kuva 18) sideaine ja väriaineet tutkittiin syksyllä 2018 Kansallisgallerian materiaalitutkimuslaboratoriossa erikoistutkija Seppo Hornytzkyjn ja tutkija Hanne Tikkalan toimesta. Vedoksessa käytetyn maalin sideaineeksi osoittautui öljy ja väriaineiksi koboltinsininen, kadmiumkeltainen, kromipitoinen vihreä sekä jokin orgaaninen punainen väriaine. Lisäksi vedoksesta tunnistettiin hieman lyijyvalkoista sekoittuneena muihin väriaineisiin. Orgaaninen punainen väriaine on mahdollisesti alitsariini, sävyltään kylmä punainen väriaine. Kyseiset väriaineet olivat Thesleffin aikaan nimenomaan taidemaalareiden laajalti käyttämiä perusväriaineita. ${ }^{82}$ Niitä tavataan 
yleisesti esimerkiksi Thesleffin aikalaiskollegan Akseli Gallen-Kallelan tuotannosta läpi uran. ${ }^{83}$

Verrataan nyt kolmen monivärisen Marionetteja-vedoksen (Kuvat 1, 2 ja 18) värejä Thesleffin luonnoksiinsa tekemiin kirjallisiin muistiinpanoihin ja luonnosten kohteena olleisiin marionettinukkeihin. On ilmeistä, että Thesleff ei ole noudattanut nukkejen asujen väritystä siirtyessään vedostusvaiheessa valitsemaan värejä laatalleen. Joitakin yhtäläisyyksiä sentään on löydettävissä, sillä Donna Silvian asu on kaikissa tunnetuissa viidessä värivedoksessa yleissävyltään punainen. Florindon alaraajat puolestaan ovat aina violetit ja maurin kasvot siniset. Florindon polveen ulottuvat mustat villakangashousut ovat siten muuttuneet koko säären ja reiden osalta "mustiksi", toisin sanoen sinisestä ja punaisesta sekoitetuksi tummanpuhuvaksi violetinsävyksi. Maurin housut ovat kolmessa vedoksessa viidestä mustan sijasta punaiset, vaikka Thesleff merkitsi tämän takin punaiseksi. Silvian avoimet puolipituiset hihansuut ja koko ylävartalo saavat välillä keltaisen sävyn, vaikka Thesleff oli nähnyt karnevaaliasuisen daamin kantavan keltaista viittaa.
Siitä huolimatta, että Thesleff on värivedoksissaan ottanut suuria vapauksia hahmojensa asujen värityksen suhteen, on maurin muita tummempi ihonväri ikuistettu kaikkiin viiteen tunnettuun värivedokseen, kuten myös mustaan Marionetteja-vedokseen ja The Maskin mustaan painokuvaan. Vedosten värimaailma tuntuukin irrottautuvan etnisyyksien kuvaamisesta, kuitenkin vain sen verran, että Othello-teema on vielä tunnistettavissa. Värit eivät jäljittele nukkejen värejä, mitä emme tietäisi, jos emme voisi verrata värejä marionettinukkeihin. Thesleffin värivedokset ovat siten dialogissa niin nukkejen, Othello-näytelmän kuin myös Craigin lehden mustavalkoisuuden kanssa, mutta hyvin omalakisesti ja visuaalisesti informatiivisesti. Nukkejen olemassaolo mahdollistaa siten taiteilijan luomisprosessin seuraamisen ja Thesleffin taiteen "itsenäisyyden" havainnoimisen. Merkitykselliseltä vaikuttaa myös se, että hahmoja jää jäljelle vain kolme.

\section{Mielleyhtymä Othelloon}

Miksi Thesleff sitten nimesi luonnoksensa Shakespearen näytelmän mukaan? Marionetteja julkaistiin Gordon Craigin artikkelin

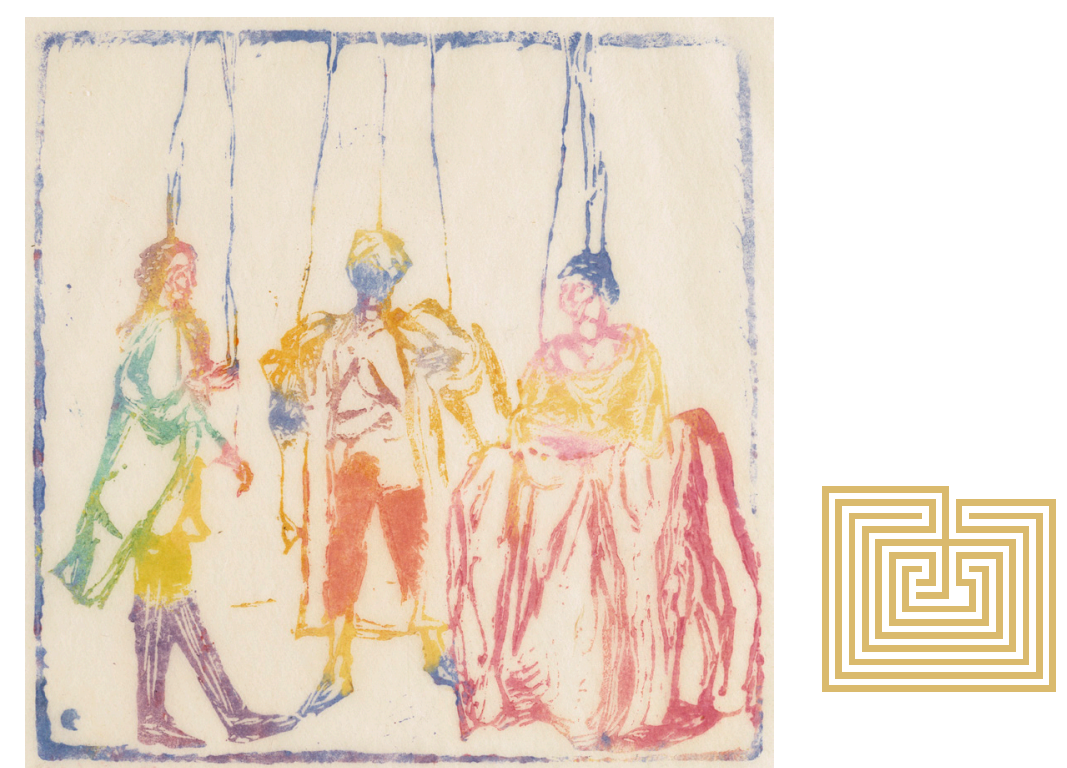

Kuva 18. Ellen Thesleff, Marionetteja, väripuupiirros, painolaatta 1908, 9,5 x 9,5 cm, vedoslehti ajoittamaton, $18,0 \times 15,2 \mathrm{~cm}$. Kansallisgalleria / Ateneumin taidemuseo, Helsinki. Kuva: Kansallisgalleria / Jouko Könönen.

"The Artists of the Theatre of the Future" välittömässä läheisyydessä, mutta artikkeli ei vastaa tähän kysymykseen. Siinä Craig kehitteli ajatustaan teatteriesityksen kaikkia osa-alueita suvereenisti hallitsevasta ja hallinnoivasta ohjaajahahmosta. Tämän alaisuudessa toimivilla näyttelijöillä oli kuitenkin 
itsenäisiä luovan ilmaisun vapauksia ja velvollisuuksia. ${ }^{84}$ Tämän ajatuksen kehittelyyn Craig sai teatterintutkija Olga Taxidoun mukaan inspiraatiota commedia dell'arte -näyttelijöiden improvisaatiosta. Nämä kunnioittivat ennalta asetettua juonta, jonka puitteissa hahmot improvisoitiin esityksestä toiseen varioiden. Näytelmillä ei ollut kirjoitettua käsikirjoitusta eikä siten alkuperäistä kirjoittajaa. Tämä teki Craigin silmissä commedia dell'artesta nimenomaan näyttelijäntyön taidetta. Tämä vapaus kiehtoi Craigia, joka haaveili esityksistä kokonaistaideteoksina, joilla ei ohjaajan lisäksi olisi muita auktoriteetteja. ${ }^{85}$

Taxidou näkee, että Craigin commedia dell'arten historiaan liittyvä projekti The Mask -lehden myöhempien vuosikertojen sivuilla pyrki muun muassa osoittamaan brittiyleisölle, että jo ennen Shakespearen aikaa oli ollut varteen otettavia teatterin tekijöitä ja että Shakespeare lainasi vanhemmasta traditiosta. ${ }^{86}$ Shakespearen Othello-näytelmän juoni on saanut suoria vaikutteita italialaisen "Cinthion" eli Giambattista Giraldin kertomuksesta Un Capitano Moro kokoelmassa Gli Hecatommithi (1565). Tarinassa päähenkilön, Venetsian kaupunkivaltion armeijaa komentavan maurin, vaimo on ylhäinen nainen nimeltä Disdemona. ${ }^{87}$ Thesleff on luonnoksissaan nimennyt hahmonsa Shakespearen Othello-näytelmän mukaan: Desdemona, Otello ja Jago.

Näytelmän tapahtumapaikka on Venetsia ja lisäksi sen miehittämä Kyproksen saari, tarkemmin saaren tärkein satamakaupunki Famagusta. Ajankohta on historiallinen kevät 1570 ennen Lepanton taistelua 1571, jossa paavin johtamat kristityt estivät ottomaanien vallan laajentumisen Välimerelle. Turkki kuitenkin valloitti Kyproksen, ja tämän seurauksena Venetsia menetti saaren hallinnan. ${ }^{88}$ Teatterin ja kirjallisuuden tutkija Emily C. Bartelsin mukaan tämä merkitsi samalla myös Venetsian kaupunkivaltion suurimman kukoistuskauden päättymistä. ${ }^{89}$ Ajankohdan historiallinen merkitys ei avaudu marionettiteatteria katsomalla, vaan se täytyy tuntea muuta kautta.

Gordon Craigin edesmennyt arkkitehti-isä E. W. Godwin (1833-1886) oli tuntenut Othello-näytelmän historiallista taustaa hyvin, mistä kertoo hänen kirjoittamansa artikkeli näytelmän lavastuksellisista mahdollisuuksista The Architect -lehteen vuonna 1875.90 Craig oli vuonna 1897 kerännyt talteen isänsä kaksikymmenosaisen artikkelisarjan Shakespearen näytelmien lavastamisesta. ${ }^{91}$ Godwinin artikkeli "The Architecture and Costume of Shakespeare's Plays - Othello" ilmestyi uudelleen The Mask -lehden sivuilla vuonna 1910, mutta sarjan uudelleen julkaisu aloitettiin Venetsian kauppiaalla jo kaksi vuotta aiemmin numerossa, jossa oli mukana myös Thesleffin Marionetteja. ${ }^{92}$ Siten Craig on mitä todennäköisimmin tuolloin tuntenut Othello-näytelmän historiallisen kytköksen.

Thesleffin Marionetteja julkaistiin The Mask -lehdessä kuvatekstillä "Marionettes in Venice: lago - Othello - Desdemona".93 Tämä noudatteli venetsialaista tapaa nimetä marionetit julkaisuissa kaupungin omaa kulttuuriperintöä korostavalla tavalla, vertailukohtana La Letturan ja Nayan studion valokuvan kuvatekstit (Kuvat 10 ja 11).

Othello-näytelmä oli 1900-luvun alkuun mennessä laajalti tunnettu. Marionettiripustuksen keskushahmoksi oli valittu kokoelman kahdesta maurinukesta vauraammin puettu. Kolme keskushahmoa oli aseteltu suhteessa toisiinsa niin, että näiden välille saattoi kuvitella kehittyvän sosiaalisia suhteita. Näyttämön päätähtien asettelu saattoi viedä ajatukset kolmiodraamaan, josta Othellossakin oli 
kyse. Tätä katsojan ei kuitenkaan tarvinnut tietää, sillä hän saattoi aavistaa sen visuaalisesti.

Maurin asu on vauraudessaan huomiota herättävä. Hänen päällystakkinsa on valmistettu lintuniisisidoksella koristellusta silkkikankaasta ja hänen vyötäisillään on keltaiseksi värjättyä kilinvuotaa. ${ }^{94}$ Näytelmässäkin hänet mainitaan "koko heimoaan rikkaammaksi" sekä henkilöksi, joka "ei kaipaa esittelyä Venetsian silmäätekevien parissa". ${ }^{95}$ Näytelmässä mauri on afrikkalaista alkuperää oleva palkkasoturi ja Venetsian hallitsijan luotettu kenraali, joka on nimetty Kyproksen käskynhaltijaksi. Hänellä on Venetsian kannalta keskeinen rooli Kyproksen puolustuksessa. ${ }^{96}$ Vaikuttaakin siltä, että Museo Civicossa työskennellyt Fondaco dei Turchin näyttelysalin marionettinukkejen ripustuksesta vastannut ammattilainen on tuntenut joko Shakespearen Othello-näytelmän tai Cinthion tarinan Un Capitano Moro tai molemmat. Nukkejen esillepano on tarjonnut tilaisuuden antaa näiden ilmentää tarinaa "Venetsian maurista", kaupunkivaltion omasta sankarista.

\section{Teoslähtöinen tutkimusasenne}

Taiteilijalle teoskeskeinen lähestymistapa on luonteva lähtökohta tutkimukselle. Yh- den teoksen näkökulmasta tutkimus avautuu moneen suuntaan ja synnyttää liudan tutkimuskysymyksiä. Konteksti rakentuu yhden teoksen ympärilleen vaatimista seikoista, ei niinkään käsitellyn aikakauden, ilmiön tai taiteilijan koko tuotannon esittelyn vaatimuksista käsin. Perspektiivi vaihtuu lintuperspektiivistä sammakkoperspektiiviin ja panoraamakuvasta huoneen kokoiseen kuvaan. Huoneessa on muutama juuri valmistunut teos ja muutama on työn alla. Ikkunoista avautuu näkymiä ympäröivään todellisuuteen. Huoneenkokoinen näkymä mahdollistaa huomion kohdentamisen tuotannon hyvinkin rajattuun aikaikkunaan. Taiteilijan koko tuotannon hahmotus tästä tutkimusnäkökulmasta jää kuitenkin vain etäiseksi haaveeksi.

Thesleffin luonnostelemat neljä nukkea löytyivät Venetsiasta neljänkymmenenkolmen säilyneen marionettinuken kokoelmasta. Niiden materiaalinen evidenssi oli edelleen tallessa. Tutkivalle taiteilijalle palkinto tuli hetkenä, jolloin sain helmikuussa 2017 katsoa samoja marionettinukkeja, joita Thesleff oli katsonut kesäkuussa 1907 samalla, kun hänen kätensä oli vetänyt lyijykynäviivaa luonnoskirjan lehdelle. Vaikka paluu tuo- hon kesäkuiseen hetkeen on mahdotonta, ovat Thesleffin luonnokset todisteita havainnosta tietyllä historiallisella hetkellä: kuinka Thesleffin silmä on katsonut, aivot rekisteröineet ja prosessoineet nähtyä ja samalla käsi on tarkasti liikuttanut lyijykynää luonnoskirjan lehdellä piirtäen muistiin kaiken oleellisen havaitusta kohteesta. Taiteilija on piirtämällä pannut muistiin visuaalisen faktan, joka ei käänny sanoiksi, ja kirjoittamalla kirjannut ylös värihavainnon, jolle on olemassa epätarkka sanakoodistonsa. Näissä luonnoksissaan hän tallensi havaintonsa, otti mukaan tarvitsemansa ja siirsi piirtämänsä ääriviivan myöhemmin laatalleen hyvin identtisenä suhteessa luonnoksiin. Värien kanssa hän sen sijaan otti suuria vapauksia. Nämä kuvallis-materiaaliset lähteet riittivät marionettinukkejen löytämiseen. Nukkejen löytäminen puolestaan mahdollisti näköhavainnon todistamisen, toisin sanoen havaintoon perustuvan kuvan todistusarvon osoittamisen.

Grimani dei Servi -suvun marionettikokoelma ja Thesleffin neljä luonnosta ovat materiaalisia jäännöksiä, arkeologisia aarteita ja ympäristönsä ei-materiaalisten suhteiden tallenteita. Marionettinukkekokoelma tallensi 
1700-luvun venetsialaisen yhteiskunnan sosiaalisia, taloudellisia ja kulttuurisia suhteita. Luonnokset puolestaan tallensivat taiteilijan ja hänen katseensa kohteen välistä suhdetta. Sekä marionettiteatteri esityksineen että Thesleffin luonnokset ja vedokset nautitaan katseen avulla, mutta samaan aikaan ne ovat pitkälle hiotun käsityötaidon näytteitä.

\section{Viitteet}

1 John Shapley, "Michael Baxandall. Painting and Experience in Fifteenth Century Italy. Oxford, Clarendon Press, 1972", Art Journal 35, no. 3 (1976) 294-296.

2 Karen Lang, "Encountering the Object", in The Lure of the Object, ed. Stephen Melville (Williamstown: Sterling and Francine Clark Art Institute, 2005), 135-140.

3 James Elkins, "On Some Limits of Materiality in Art History", 31. Das Magazin des Instituts für Theorie,

Zürich Nr. 12 (2008): 25 (ks. myös päivitetty versio Elkinsin Academia.edu -sivulla, luettu 2.12.2020, https://www.academia.edu/168260/On Some Limits of Materiality in Art History).

4 Ks. myös tämän artikkelin kanssa samanaikaisesti työstämäni artikkeli "Väriä päin - Ellen Thesleffin varhaiset kohopainolaatat ja värivedokset", teoksessa Printed Matters. Merkitysten kerroksia, toim. Martta Heikkilä \& Annu Vertanen (Helsinki: Taideyliopiston Kuvataideakatemia, tulossa 2021). E. J. Vehmaksen artikkelin "Ellen Thesleff graafikkona" (Suomen Taidegraafikoiden vuosikirjassa Vedos '70, 1970: 8-20) tietoja Thesleffin kohopainovedoksissaan käyttämistä materiaaleista verrattiin aloitteestani Kansallisgallerian kokoelmissa olevien Thesleffin varhaisimpien päivättyjen värillisten vedosten materiaalianalyyseihin vuosina 2018-2020. Sideaineja väriaineanalyysit toteuttivat erikoistutkija Seppo Hornytzkyj ja tutkija Hanne Tikkala Kansallisgallerian materiaalitutkimuslaboratoriossa. Kuituanalyysit toteuttivat konservoinnin lehtori, paperikonservaattori Päivi Ukkonen ja paperikonservaattori Sara Théodore Metropolian ammattikorkeakoulun konservoinnin laboratorioissa. Kansallisgallerian kokoelmissa oleva Marionetteja-vedos lukeutui tutkittuihin teoksiin. 5 Esimerkkini ovat viimeaikaisesta Theslefftutkimuksesta, mutta teoreettinen lähestymistapa visuaalis-materiaalisiin lähteisiin on taidehistorian kentällä vallalla laajemminkin. Marja Lahelma, "Maapallon sydämenlyönnit - Ellen Thesleff ja elämänvoima", Tahiti 9, nro 3 (2019): 22-39, luettu 28.11.2010, https://doi.org/10.23995/tht.88663; Riikka Stewen, "Ilman ja liikkeen fenomenologiasta - Ellen Thesleff, Isadora Duncan, Edward Gordon Craig", Tahiti 9, nro 3 (2019): 40-52, luettu 28.11.2020, https://doi.org/10.23995/tht.88670. Valittujen esimerkkiartikkelien argumentaatio ei olisi kärsinyt teoskuvien pois jättämisestä. Lahelman artikkelissa on vain kolme teoskuvaa ja Stewenilläkin vain kaksi teoskuvaa kuvituksena ja yksi kuva Thesleffin luonnoksesta osana argumentaatiota. Käytetyt lähteet puolestaan olivat Stewenin artikkelin yhtä luonnosta lukuun ottamatta tekstuaalisia.

6 Ludmilla Jordanova, "Approaching Visual Materials", in Research Methods for History, eds. Simon Gunn \& Lucy Faire (Edinburgh: Edinburgh University Press, 2011), 31, 37, 41.

7 Michael Baxandall, Painting and Experience in Fifteenth Century Italy (Oxford: Clarendon Press, 1972), 1-2. Ks. myös Baxandallin myöhempi, Suomessakin laajalti hyödynnetty metodologinen teos Patterns of Intention: On the Historical Explanation of Pictures (New Haven: Yale University Press, 1985). 8 Baxandall, Painting and Experience in Fifteenth Century Italy, 2.

9 Michael Yonan, "The Suppression of Materiality in Anglo-American Art-Historical Writing", The Challenge of the Object-Die Herausforderung des Objekts. Proceedings of the 33rd Congress of the International Committee of the History of Art (CIHA), Nürnberg, 15-20 July 2012, hrsg. Georg Ulrich Großmann \& Petra Krutisch (Nürnberg: Verlag des Germanischen Nationalmuseums, 2012), I: 63.

10 James Elkins, "On Some Limits of Materiality in Art History", 31.

11 Michael Yonan, "Materiality as Periphery", Visual Resources 35 no. 3-4 (2019): 200, 212-213.

12 Jordanova, "Approaching Visual Materials", 40.

13 Jordanova, "Approaching Visual Materials", 31, 33,

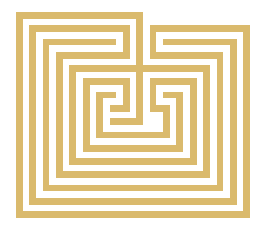


35-37, 41-42, 44.

14 Paavilainen, "Väriä päin".

15 Jordanova, "Approaching Visual Materials", 30, 31, 36.

16 Tutkimuksesta ks. Erkki Anttonen, Kansallista vai modernia. Taidegrafiikka osana 1930-Iuvun taidejärjestelmää (Helsinki: Valtion taidemuseo, 2006), 538-542; Monica Schalin, Målarpoeten Ellen Thesleff. Teknik och konstnärligt uttryck (Åbo: Åbo Akademis förlag, 2004); Maria Rosa Ventimiglia,

Un'artista finlandese a Firenze, pro gradu -tutkielma, Università degli studi di Firenze, 2014 (tuloste Kansallisgallerian kirjastossa); Kukka Paavilainen,

Puugrafiikan vaikutus Ellen Thesleffin maalauksiin 1908-1912, pro gradu -tutkielma, Helsingin yliopisto, 2016; Asta Kihlman, Kolme tutkielmaa sukupuolesta. Identiteettipolitiikka Beda Stjernschantzin, Sigrid af Forsellesin ja Ellen Thesleffin taiteessa (Turku: Turun yliopisto, 2018). Pro gradu -tutkielmani aihe syntyi kirjoittaessani artikkelia "Veitset - Ellen Thesleffin vapauden välineet" nuoren taidemaalarikollegan näkökulmasta Ellen Thesleff - Värien tanssi -näyttelyjulkaisuun, toim. Ilkka Karttunen \& HannaReetta Schreck (Helsinki: Taidekeskus Retretti, 2008), 97-103.

17 Thesleff oli Pariisin opintojensa päätteeksi suunnannut Italiaan ensi kertaa jo vuonna 1894.

Leena Ahtola-Moorhouse, "Elämäkerrallisia tietoja", teoksessa Ellen Thesleff, toim. Leena AhtolaMoorhouse (Helsinki: Ateneum, 1998), 14-16. 18 Lilli-äidin kirje Ellen ja Gerda Thesleffille Bolzanoon Italian pohjoislaidalle sunnuntaina 26.8.1906 (postileima 27.8.1906), Familjen Thesleffs arkiv (SLSA 958), Svenska litteratursällskapet i

Finland; Ahtola-Moorhouse, "Elämäkerrallisia tietoja", 16.

19 Paavilainen, Puugrafiikan vaikutus Ellen Thesleffin maalauksiin 1908-1912, 26-27.

20 Ahtola-Moorhouse, "Elämäkerrallisia tietoja", 16; Hanna-Reetta Schreck, Minä maalaan kuin jumala. Ellen Thesleffin elämä ja taide (Helsinki: Teos, 2017),
164-165. Molempien tieto tapaamisajankohdasta perustuu Ellen Thesleffin Gordon Craigille 22.2.1933 lähettämään kirjeeseen (Bibliothèque Nationale de France).

21 Dorothy Nevile Lees, "'Notes on Work with Gordon Craig and the Mask in Florence' From the Beginning of 1907 Onwards" (julkaisematon käsikirjoitus vuodelta 1961, IT ACGV DNL.II.5.2), Archivio Contemporaneo "Alessandro Bonsanti" (Firenze), Gabinetto G.P. Vieusseux, 8.

22 Edward Braun, The Director and the Stage: From Naturalism to Grotowski (New York: Holmes \& Meier Publishers, 1982), 77-94. Craigin Rosmersholm-

ohjaus jäi historiaan. Seuraava toteutunut ensi-ilta nähtiin tammikuussa 1912 Moskovan Taiteellisessa Teatterissa, kun Craig ohjasi Konstantin Stanislavskin kutsusta Shakespearen Hamlet-näytelmän, joka sekin jäi historiaan. Ks. myös Edward Craig, Gordon Craig: The Story of his Life (London: Victor Gollacz, 1968), 244-245, 267-275.

23 Lees, "Notes", 9-10.

24 Lees, "Notes", 10; The Mask, edited by Edward Gordon Craig, Florence 1909-1929, reissued 1966 with an index compiled by Loreley F. Guidry (New York: Benjamin Blom, 1966). "The Actor and the Über-marionette", The Mask 1, no. 2 (April 1908): 3-15, "To Madame Eleonore Duse" The Mask 1. no. 1 (March 1908): 12-13, "A Letter to Ellen Terry from Her Son", The Mask 1, no. 6 (August 1908): 109-111. Alkuperäisiä The Mask -lehden vuosikertoja olen tarkastellut Biblioteca Nazionale Centrale di Firenzessä. Tässä artikkelissa käytän vuoden 1966 näköispainosta, joka löytyy mm. Kansallisgallerian kirjastosta. Alkuperäiset lehdet ks. myös (luettu 30.11.2020):

https://bluemountain.princeton.edu/exist/apps/ bluemountain/title.html?titleURN=bmtnaau Valitse haluamasi lehden numero, paina "pdf" ja selaa.

25 Craig, Gordon Craig, 232; Ahtola-Moorhouse, "Elämäkerrallisia tietoja", 16. Edward Craig mainitsee
Ellen "Tesleffin" nimeltä sivulla 232 sekä tekniikaksi puukaiverruksen, kun taas Ahtola-Moorhouse mainitsee tekniikaksi puupiirroksen. Thesleff teki lehteen tiettävästi molempia, mutta laattojen puuttuessa ei tekniikkojen erotteluun tule lopullista varmuutta. Ks. Paavilainen, "Väriä päin".

26 Craig, Gordon Craig, 230-232.

27 Lees, "Notes", 13.

28 The Mask 1, no. 1 (March 1908): 9-12.

29 Lista Gordon Craigin The Maskissä käyttämistä lukuisista pseudonyymeistä, Mark Duvillier, The Mask [1908-1929] de Edward Gordon Craig. "Un rêve mis noir sur blanc", väitöskirja, École doctorale Arts et

médias, Université Sorbonne Nouvelle, Paris 3, 2009, 951.

30 "The Artists of the Theatre of the Future", The Mask 1, no. 1 (March 1908): 3-5; The Mask 1, no. 3-4 (May-June 1908): 57-70 (Marionetteja-kuvitus $70 b)$.

31 Tunnetuin värivedos on Kansallisgallerian

kokoelmissa, toinen Joensuun taidemuseossa Olavi Turtiaisen kokoelmassa ja kolme yksityiskokoelmissa. Niin ikään musta vedos on yksityiskokoelmassa.

32 Thesleffin varhaisin säilynyt puupiirroslaatta (yksityiskokoelmassa) on vuodelta 1914-1915. Kaikki varhaiset puukaiverruslaatat ovat kadonneet. Kansallisgallerian kokoelmissa olevat Thesleffin laatat ovat pääasiassa puupiirroslaattoja ja varhaisimmat niistä ovat vuodelta 1924.

33 Leena Ahtola-Moorhouse, "Teosluettelo", teoksessa Ellen Thesleff, toim. Leena AhtolaMoorhouse, Ateneumin julkaisut no 7 (Helsinki: Ateneum, 1998), 127.

34 The Mask -lehden sisällysluettelossa (3-4 MayJune 1908, 53) Thesleffin Marionetteja nimetään puukaiverrukseksi. Leonard Bäcksbacka taas ei erottele tekniikkoja vuonna 1955 ilmestyneen Ellen Thesleff -monografiansa (Helsingfors:

Konstsalongens förlag, 1955, 174) teosluettelossa vaan puhuu tämän kaikista kohopainoteoksista termillä "träsnitt", puupiirros. Ateneumin

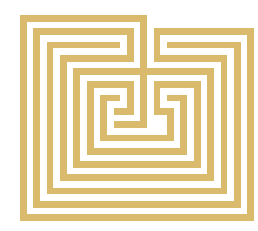


taidemuseon Ellen Thesleff -näyttelyjulkaisun (1998) teosluettelossa teokset on eritelty puupiirroksiin ja puukaiverruksiin. Marionetteja on teosluettelossa puupiirroksena. (Ahtola-Moorhouse, "Teosluettelo", 146.) Tähän näkemykseen yhtyy myös taidegraafikko Inari Krohn, joka tekee sekä puupiirroksia että puukaiverruksia (sähköposti Kukka Paavilaiselle 27.8.2020)

35 Marionetteja-laatan ja -vedosten ajoitus vuodelle 1907 on spekulatiivinen. Ennen Marionetteja-teosta The Mask -lehdessä julkaistiin Thesleffiltä vain kolme naamioaihetta, joiden luonnoksia löytyy jo vuoden 1907 puolelta. The Mask -lehden ensinumerossa (maaliskuu 1908) naamioaiheiden tekniikkaan ei oteta kantaa, eikä niitä huomioida lainkaan Bäcksbackan (1955) tai Ateneumin taidemuseon (1998) teosluetteloissa. Marionetteja-vedosten ajoitus vuoden 1907 lopulle vaikuttaakin perustuvan Bäcksbackan teosluetteloon (1955, 174), jonka kohopaino-osuus alkaa Marionetteja-laatalla.

Bäcksbackan ajoitus taas mitä ilmeisimmin perustuu Thesleffin kirjeeseen veljelleen Eynarille joulupäivänä 1907. Siinä taiteilija mainitsee saaneensa jonkin puupiirrosvedoksen valmiiksi jo ennen joulua, mutta ei mainitse teosta nimeltä. Thesleffin kirjeen hihkaisua koskien syntyneen vedoksen korkeatasoisuutta ei tule tulkita Bäcksbackan $(1955,45)$ tapaan "objektiiviseksi huomioksi aikakauden parhaimmasta teoksesta". Kyse on nähdäkseni taiteilijan onnesta syntyneen teoksen äärellä, mistä kertovat vastaavat hihkaisut kirjeissä myöhemminkin uralla. Ne ilmaisevat taiteilijan subjektiivisen hetkellisen kokemuksen. Marionetteja-vedosten ajoitukselle jo vuodelle 1907 ei siten ole minkäänlaisia takeita. (Ellen Thesleffin kirje Einar-veljelleen Firenzestä Helsinkiin 25.12.1907,

SLSA 958; Bäcksbacka, Ellen Thesleff, 45, 174;

Paavilainen, "Väriä päin".)

36 Paavilainen, "Väriä päin".

37 Bäcksbacka, Ellen Thesleff, 45. Käännös kirjoittajan.

38 Kansallisgallerian inventaarionumero A IV 3449:25, sivut 113, 115, 117, 119.

39 Suullinen tiedonanto Giorgio Marini, Galleria degli Uffizi Firenze, Gabinetto dei Disegni e delle Stampe 24.1.2017.

40 Puupiirroslaattojen tarkastelu ja ajoitus

kokoelmadatassa Stefania Galetton avustuksella,

Museo Correr, Venetsia 21.2.2017.

41 Giandomenico Romanelli, "The Museum Network: From the Correr to the Fondazione", in Venice: The Museo Correr, ed. Sergio Brugiolo (Venice \& Milan:

Fondazione dei Musei Civici di Venezia \& Skira \& Marsilio editori, 2010), 9-12.

42 Alun perin satapäisen marionettinukkekokoelman

lahjoitti Salvatore Arbib vuonna 1896. Kuvan

11 vasemmassa reunassa näkyy pieni kyltti

"Dono ARBIB". Saman kuvan jo tuhoutuneen

teatterirakennuksen lahjoitti niin ikään vuonna

1896 suvun jäsen Fausto Orrefice. Rakennuksen

yläosassa näkyy Grimani dei Servi -suvun vaakuna.

Patrizia Bonato, "Catalogo delle opere", teoksessa Le

marionette delle collezioni dei Musei Civici Veneziani

(Venezia \& Milano: Fondazione Musei Civici Venezia \& Skira, 2010), 33.

43 Suullinen tiedonanto Cristina Crisafulli ja Andrea Bellieni, Museo Correr 21.2.2017.

44 Romanelli, "The Museum Network", 12.

45 Ricciotti Bratti, "Marionette del settecento", La

Lettura, rivista mensile del Corriere della Sera, Anno

X, n. 1, gennaio 1910: 59, arkistossa Biblioteca Casa Goldoni (Venetsia), 5 D 52.

46 Carlo Nayan valokuva, Museo Correr, Venetsia.

Kahden valokuvan yhteenkuulumista koskeva

suullinen tiedonanto Andrea Bellieni, Museo Correr,

Venetsia 21.2.2017. En ole saanut selville, milloin

museon nimi vakiintui Museo Correriksi.

47 Molly Rogers, "Naya, Carlo (1816-1882)", The

Oxford Companion to the Photograph, ed. Robin

Lenman (Oxford: Oxford University Press, 2005), 438.

48 Silvia Paoli, "Naya, Carlo (1816-1882)",

Encyclopedia of Nineteenth-Century Photography,

ed. John Hannavy (New York \& London: Routledge,
2008), 982.

49 Suullinen tiedonanto, Anna Bogo, Biblioteca Casa Goldoni 20.2.2017.

50 Salme Sarajas-Korte, "Ellen Thesleffin vuodet 1890-1915", teoksessa Ellen Thesleff, toim. Leena Ahtola-Moorhouse (Helsinki: Ateneum, 1998), 59.

51 Schreck, Minä maalaan kuin jumala, 182.

52 Craig, Gordon Craig, 229, 232-275; Braun 1982, 89-93. Näytelmän ensi-illan yhteydessä ohjaajien yhteistyö ilmaistiin muodossa, jossa Stanislavski mainittiin ohjaajana ja Craig vastasi vain lavastuksesta ja puvustuksesta.

53 Ellen Thesleffin kirje Lilly-äidilleen Firenzestä Helsinkiin 8.9.1909, SLSA 958.

54 Vehmas, "Ellen Thesleff graafikkona", 5.

55 Suulliset tiedonannot Anna Bogo, Biblioteca Casa Goldoni 20.2.2017 ja Andrea Bellieni, Museo Correr

21.2.2017 sekä sähköpostitiedonanto Francesca

Pederoda, Museo e Centro di Studi Teatrali Casa di Carlo Goldoni 26.10.2020.

56 Guido Marta, "Le Marionette a Venezia", II

Gazzettino Illustrato 26.11.1926, arkistossa Biblioteca di Casa Goldoni (Venetsia), Miscellanea Musatti, 5 F 171.

57 Bonato, "Catalogo delle opere", 13-33;

Giacomo Oreglia, Commedia dell'Arte. Maskerna, komedianterna, scenarierna (Stockholm: Ordfront, 2002), 11-13, 73-156.

58 Romanelli, "The Museum Network", 12.

59 Ks. Ca' Rezzonicon kokoelmasivut, luettu

1.9.2020, http://www.archiviodellacomunicazione. it/sicap/lista/any:tiepolo, \%20Giandomenico, \%20 pulcinella/page:1/?WEB=MuseiVE.

60 Oreglia, Commedia dell'Arte, 181

61 Oreglia, Commedia dell'Arte, 199-200.

62 Bonato, "Catalogo delle opere", 15-16, 20-21.

Kamarineidot löytyvät Nayan studion valokuvasta ylärivin keskeltä, keskiriviltä neljäntenä oikealta ja alariviltä toisena oikealta.

63 Bonato, "Catalogo delle opere", 18, 21-23, 25.

64 Bonato, "Catalogo delle opere", 15, 18, 20-23,

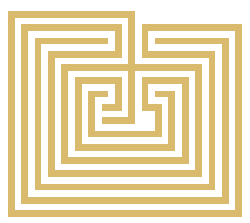


25-29.

65 Bonato, "Catalogo delle opere", 13-33.

66 Anna Bogo (Biblioteca Casa di Carlo Goldoni),

sähköposti Kukka Paavilaiselle, 28.3.2017 ja

Francesca Pederoda (Museo e Centro Studi

Teatrali Casa di Carlo Goldoni), sähköposti Kukka

Paavilaiselle 1.12.2020.

67 Bonato, "Catalogo delle opere", 18

68 Bonato, "Catalogo delle opere", 16, 21.

69 Bonato "Catalogo delle opere", 16.

70 Oreglia, Commedia dell'Arte, 183

71 Bonato,"Catalogo delle opere", 14, 20.

72 Paavilainen, "Väriä päin".

73 Bonato, "Catalogo delle opere", 19, 24

74 Bonato, "Catalogo delle opere", 19

75 Oreglia, Commedia dell'Arte, 181-183.

76 Bonato, "Catalogo delle opere", 18-19, 24.

77 Gunnel Hazelius-Berg, Modedräkter från 1600-

1900 (Stockholm: Nordiska museet, 1952), 8-10.

78 Giovanni Mariacher, Ca'Rezzonico: An Illustrated

Guide (Venice: Alfieri, 1967), 37-38, kuva nro 296.

79 Bonato, "Catalogo delle opere", 26.

80 Suullinen tiedonanto Anna Bogo, Museo Casa di

Carlo Goldoni 20.2.2017.

81 Kansallisgallerian inventaarionumero C IV 760

82 Paavilainen, "Väriä päin".

83 Hanne Tikkala \& Seppo Hornytzkyj,

"Luonnontieteellisin analyysimenetelmin tunnistettu Akseli Gallen-Kallelan väripaletti", Tahiti 10, nro 1 (2020): 5-6, 10, luettu 1.9.2020, https://doi. org/10.23995/tht. 90554 .

84 Gordon Craig, "The Artist of the Theatre of the

Future", The Mask 1, no. 1 (March 1908): 4;

"The Artist of the Theatre of the Future (Continued)",

The Mask 1, no. 3-4 (May-June 1908): 58, 65,

68-69.

85 Olga Taxidou, The Mask: A Periodical Performance

by Edward Gordon Craig (London \& New York:

Routledge, 2013), 117, 121-122, 124-129, 132.

86 Taxidou, The Mask, 120-121.

87 Emily C. Bartels, Speaking of the Moor: From
Alcazar to Othello (Philadelphia: University of Pennsylvania Press, 2008), 156; John Edward Taylor, The Moor of Venice: Cinthio's Tale and Shakespeare's Tragedy (London: Chapman and Hall, 1855), 4, 15-36.

88 Bartels, Speaking of the Moor, 161; E. W. Godwin,

"The Architecture and Costume of Shakespeare's

Plays - Othello", The Mask 2, no. 10-12 (April 1910) 165-166.

89 Bartels, Speaking of the Moor, 161.

90 "Introduction", The Mask 1, no. 3-4 (May-June

1908): 75; Craig, Gordon Craig, 43-48, 241-242;

Taxidou, The Mask, 6. Julkaisuvuosi 1875 on

ilmoitettu vain The Maskin "Johdannossa".

91 Taxidou, The Mask, 6; Craig, Gordon Craig, 241-242.

92 Godwin, "The Architecture and Costume of

Shakespeare's Plays - Othello", 165-167; E. W.

Godwin, "The Architecture and Costume of the

Merchant of Venice", The Mask 1, no. 3-4 (May-June 1908): 75

93 The Mask 1, no. 3-4 (May-June 1908): 70b.

94 Bonato, "Catalogo delle opere", 26.

95 Bartels, Speaking of the Moor, 1

96 Bartels, Speaking of the Moor, 167-168, 176.
KuM, FM Kukka Paavilainen on helsinki-

läinen taidemaalari ja taidehistorioitsija,

joka tekee kuvataiteen tohtorin opinnäytettä Taideyliopiston Kuvataideakatemian tohtoriosastolla. Tutkijan kiinnostuksen kohteena ovat teoslähtöinen taidehistoria sekä lähellä taidehistoriaa tapahtuva taiteellinen tutkimus. Tutkimuksen on mahdollistanut Alfred Kordelinin säätiön apuraha.

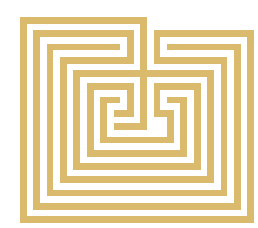

